\title{
LA TEORÍA LITERARIA EN EL FIN DE SIGLO: PANORAMA DESDE ESPAÑA*
}

\author{
JOSÉ-LUIS GARCÍA BARRIENTOS
}

Instituto de la Lengua Española, CSIC

\section{RESUMEN}

Este artículo ofrece un panorama de la investigación en teoría literaria durante el último cuarto del siglo XX y primeros años del XXI, desde la situación de la disciplina en España. No establece el inabarcable estado de la cuestión, sino que propone una visión comprometida del mismo. Después de esbozar la crisis epistemológica que lo caracteriza y tomar partido en ella, se hace lo propio con el archipiélago post-estructuralista, en el que cabe contraponer algunas modas «críticas» de Norteamérica a una cierta tradición europea más propensa a la continuidad que a la ruptura. En esta segunda línea, se destacan las siguientes tres grandes orientaciones: 1) el imperio de la lectura, con el sesgo hermenéutico y la importancia de la recepción; 2) la vuelta de la historia y sus problemas, como el canon, al centro de la discusión teórica; y 3) la convergencia en la dimensión discursiva de la poética y la retórica, cuya fecundidad y vigencia se defienden, y se ilustran con el ejemplo de la dramatología.

Palabras clave: Teoría literaria, historia de la teoría, post-estructuralismo, hermenéutica, recepción, teoría de la historia literaria, retórica, poética, dramatología.

\begin{abstract}
This paper offers a panorama of the research in Literary Theory during the last quarter of the $20^{\text {th }}$ century and the first years of the $21^{\text {st }}$. It does not intend to come to ultimate conclusions, but to offer a partisan vision of the topic. In the first part of the paper, the author gives a summary of the current «epistemologic crisis», followed by another summary of the post-structuralist trends. Regarding this first section, the author confronts some of the revolutionary theories in the current North American Scholarship to the more conservative European Tradition. In this second section, there are three big differentiated areas: 1) The massive importance of the reading, analyzed under a Hermeneutic perspective and the importance of the Reception. 2) The return of the History and some of its problems, posing the notion of «canon» in the centre of the discussion, 3) The confluence of Poetics and Rhetoric in the Discourse dimension of the Language; this last section, whose fruitful and live-to-day trajectory are described, provides the example of the Dramatology.
\end{abstract}

Key words: Literary theory, History of the theory, Post-structuralism, Hermeneutic, Reception, Theory of the literary history, Rhetoric, Poetic, Dramatology.

* Una primera versión del tercio inicial de este ensayo fue la base de la conferencia de clausura del Congreso Internacional «Teorías y Prácticas Críticas: Después de Babel», que dicté en la Universidad Nacional de Cuyo (Mendoza, Argentina) el 3 de septiembre del 2005. 
No parece tarea fácil, desde luego, dar cuenta, ni siquiera con carácter propedéutico, de lo que anuncia el título de mi artículo, esto es, del estado de la investigación sobre teoría de la literatura, área de conocimiento que ha alcanzado ya una amplitud realmente inabarcable, en este nuevo fin de siècle. Por eso intentaré esbozar, no el estado de la cuestión, sino una visión parcial o comprometida del mismo, asumiendo la parcialidad también en la cara metodológica, como solución al conflicto entre caudal informativo y carga conceptual, a favor de esta última. De modo que elijo para mi exposición el camino, quizás temerario, de subordinar la cantidad a la cualidad, la angustia por la información a la angustia, no menor, por las ideas. Y soy consciente de que tal opción entraña arriesgarse a intervenir en los datos, a manipularlos en el sentido literal de idealizarlos, procediendo a generalizaciones y simplificaciones. Con la consecuencia, en términos prácticos, de hacerlos discutibles. Pero de eso se trata, o de eso creo yo al menos que debe tratarse cuando es de teoría literaria de lo que se trata.

\section{Perspectiva: Panorama desde España}

Es muy satisfactorio poder decir, como creo, que el punto de mira desde el que asomarnos al panorama de la investigación actual en teoría literaria, o sea, la situación del área de conocimiento en España, lejos de aumentar las dificultades a que me vengo refiriendo, facilita la tarea, pues se trata con seguridad de una posición ventajosa y en algunos aspectos envidiable incluso para las culturas hegemónicas en este campo.

Destacaré sobre todo en este sentido el excelente material que proporcionan para hacerse una idea del estado de la cuestión dos colecciones editoriales: la titulada «Teoría de la literatura y literatura comparada» que publica la editorial Síntesis y dirige Miguel Ángel Garrido, y la dirigida por José Antonio Mayoral en la editorial Arco Libros con el título de «Lecturas». El diferente enfoque de cada una las hace además particularmente complementarias. La primera dedica cada volumen a dar una visión actualizada de las cuestiones que integran el temario fundamental de la materia, con sendos libros también dedicados a ofrecer una visión de conjunto de la teoría literaria en diferentes ámbitos lingüísticos ${ }^{1}$. La segunda, aunque también dedica algunos números a temas de gran calado como los géneros ${ }^{2}$, se centra sobre todo en los enfoques, escuelas o corrientes de la

${ }^{1}$ Por ejemplo, Alicia Yllera, Teoría de la literatura francesa, Madrid, Síntesis, 1996; Rita Gnutzmann, La teoría literaria alemana, Madrid, Síntesis, 1994.

${ }^{2}$ Por ejemplo, Miguel Ángel GarRIDO Gallardo (comp.), Teoría de los géneros literarios, Madrid, Arco Libros, 1988; María del Carmen Bobes NAves (comp.), Teoría del teatro, Madrid, Arco Libros, 1997; Fernando CABO AsEguinolazA (comp.), Teorías sobre la Lírica, Madrid, Arco Libros, 1999. 
teoría más reciente, de forma que ofrece un muestrario bastante representativo de las diferentes teselas del mosaico post-estructuralista. En la primera se trata de monografías escritas por profesores españoles especialistas en cada tema, con la sola excepción de la traducción de la Poética occidental de Doležel ${ }^{3}$; la segunda, en cambio, presenta la forma de antología o compilación de artículos, predominantemente traducidos de otros idiomas. Creo no equivocarme al afirmar que ni en inglés ni en francés ni en alemán cuentan con un material bibliográfico equivalente. He aquí un motivo de orgullo bien fundado y, de paso, un buen antídoto contra el papanatismo.

Ni que decir tiene que no se trata de las únicas fuentes de utilidad para nuestro propósito. Pienso, por ejemplo, en la colección «Teoría y crítica literaria» que dirigió Darío Villanueva para Taurus, de la que destacaría las traducciones de obras fundamentales (Benjamin, Booth, Jauss, Iser, etc.), o en la vigente de Arco/Libros, «Perspectivas. Biblioteca de Teoría Literaria y Literatura Comparada», que dirige María del Carmen Bobes. En lo que se refiere a la producción española, la periódica y puntual aparición, cada dos años, de la Actas de la Asociación Española de Semiótica (AES), desde el Congreso fundacional celebrado en el CSIC en 1983, en cuya organización tuve el honor de participar, viene constituyendo un depósito de material ingente; de valor desigual, claro está, pero muy útil una vez aquilatado.

También debe destacarse la labor de las revistas especializadas en teoría literaria o que dedican un espacio significativo a ella, como Revista de Literatura (del CSIC), Signa (de la AES), Tropelías (de la Universidad de Zaragoza), Discurso (de Sevilla), Teoría/Crítica (de Alicante), Exemplaria (de Huelva), Humanitas (de Jaén), Poética medieval (de Alcalá), Calamus Renascens (de Alcañiz), o Prosopopeya, de la Universidad de Valencia, que precisamente dedicó su número 1, de otoño/invierno de 1999, al debate sobre «El futuro de la teoría literaria».

Es indiscutible que nuestra disciplina ha conocido en España un desarrollo considerable durante el último cuarto del siglo XX, precisamente el periodo que tiene que enfocar, por la fuerza de los hechos, cualquier exposición del estado actual de la teoría. Y ello sobre la base de la aportación de primer orden que supone en la primera mitad del siglo la estilística española encabezada por los dos Alonso, y, más al fondo, la sólida tradición de la escuela de filología española, de la que destaco su ejemplar y excepcional atención conjunta a la lengua y la literatura, y de la que el eslabón de continuidad ha sido la obra de Fernando Lázaro Carreter ${ }^{4}$.

Pero la historia de la moderna teoría literaria en España está por hacer,

${ }^{3}$ Lubomír DoLEŽEL, Historia breve de la poética [1990], trad. de Luis Alburquerque, Madrid, Síntesis, 1997.

${ }^{4}$ Cf. Estudios de poética (La obra en sí), Madrid, Taurus, 1976. 
aunque no falten las contribuciones valiosas para conformarla ${ }^{5}$. Ojalá contáramos para el último tercio del siglo XX con un trabajo de conjunto como el que debemos a la generosa atención de Emilia de Zuleta en lo que se refiere a las primeras seis décadas largas ${ }^{6}$. Meritorios son los esfuerzos de José Romera por organizar una bibliografía de La semiótica literaria y teatral en España, entendiendo «semiótica» en un sentido tan amplio que viene prácticamente a coincidir con «teoría», tanto en el libro así titulado como en sucesivas addenda ${ }^{7}$. Sultana Wahnón ha estudiado con detalle la Estética y crítica literaria en España durante la década de los años cuarenta ${ }^{8}$. Miguel Ángel Garrido ha trazado las líneas maestras de un panorama de «La teoría literaria en España a partir de 1940»; trabajo del que me interesa destacar la conclusión de que «es indudable la existencia de una Teoría literaria hispánica», que es «científicamente solvente y original». Pero mientras que «las obras generales o de síntesis escritas en España e Hispanoamérica dan cuenta de toda la producción occidental, incluyendo la propia; las realizadas en otros países de Occidente desconocen radicalmente lo hispánico» ${ }^{9}$. Esta ausencia resulta inexplicable y sin razón objetiva que la justifique.

\section{CRISIS EPISTEMOLÓGICA}

Si se me permite teorizar todavía sobre la dificultad de mi tarea, diré que la raíz más profunda de la misma se hunde en el problema del estatuto epistemológico de nuestra disciplina (y de su objeto, la literatura, y del conjunto de los estudios literarios); problema que es sin duda uno de los aspectos más actuales, más en carne viva, de la investigación literaria.

Solicitar el «estado actual» de un tema seguramente no plantea graves problemas si ese tema pertenece a un área de conocimiento regida por el principio de progreso, como generalmente se considera que ocurre en la ciencia propiamente dicha, al menos tal como la caracterizaba Víctor Hugo

\footnotetext{
${ }^{5}$ Quede claro que este artículo no es ni pretende ser una de ellas. Intenta ofrecer un panorama de la teoría, no de sino desde España. Y un panorama, además, expresamente comprometido y por tanto sin la más mínima pretensión de exhaustividad. Así por ejemplo advierto, releyendo mi trabajo una vez terminado, que, casualmente, no aparecen citados en él profesores de cuantiosa producción bibliográfica como F. Abad Nebot o A. García Berrio, entre otros muchos.

${ }^{6}$ Emilia DE Zuleta, Historia de la crítica española contemporánea [1966], Madrid, Gredos, $2^{a}$ ed. notablemente aumentada, 1974.

7 José Romera CASTILlo, Literatura, teatro y semiótica, Madrid, UNED, 1999; Semiótica literaria y teatral en España, Kassel, Reichenberger, 1988.

${ }^{8}$ Sultana WAHNón, Estética y crítica literaria en España (1940-1950), Granada, Universidad, 1988.

9 M. A. GARRIDo Gallardo, «La teoría literaria en España a partir de 1940», en La musa de la retórica. Problemas y métodos de la ciencia de la literatura, Madrid, CSIC, 1994 (pp. 29-62), p. 62.
} 
en su William Shakespeare: «La ciencia es serie. Procede mediante pruebas superpuestas unas a otras y cuyo oscuro espesor sube lentamente hasta el nivel de la verdad»; y añadía: «Nada semejante en el arte. El arte no es sucesivo. Todo el arte es conjunto» ${ }^{10}$, vale decir un «orden simultáneo», afectado de la «presentidad» (presentness) de que hablará después Eliot. Ya sé que el optimismo que encierra esa idea de la ciencia como lenta conquista de la verdad no ha resistido intacto el paso del tiempo (o mejor, de la filosofía de la ciencia, pues lo que se ha producido en la realidad es la sucesión, vertiginosamente acelerada y pasmosa, de avances científicos).

Pero que una obra como la Poética de Aristóteles pueda considerarse hoy, como yo mismo he sostenido, no sólo fundacional sino también «fundamental» de nuestra disciplina, significa afirmar que puede leerse hoy mismo como teoría, no o no sólo como historia de la teoría. Así creo yo que fue leída por los humanistas del Renacimiento y hasta el siglo XIX, por lo menos; como teoría viva, vigente; lo mismo que, en el siglo XX, por los formalistas rusos, por la escuela de Chicago o por los estructuralistas franceses. Así he pretendido yo mismo leerla cuando he concebido expresamente mi programa principal de investigación como el desarrollo de un aspecto casi obviado en el portentoso librito, el de una teoría del «modo» dramático de representación; y hasta he dedicado un capítulo en uno de mis libros a mostrar la vigencia de su sistema conceptual para una metodología - se entiende actual- de análisis dramático ${ }^{11}$. Esto emparenta a la Poética y en general a los clásicos de la teoría mucho más con los clásicos de la literatura - El Quijote, La Odisea - que con los de la ciencia, que sólo admiten ser leídos como historia, no como ciencia.

Así, pues, debemos ser conscientes de la ambigüedad que afecta a lo «actual» en nuestro campo: ¿el estadio más avanzado, por no decir más cercano a la verdad, o sencillamente la última moda? Al enumerar las corrientes hoy más en boga, no deja uno de tener la sensación de estar barajando algo así como las últimas modas de Norteamérica, con el matiz también de globalización o colonización cultural, inevitable en casi todos lo órdenes. ¿También en éste? Pero lo más grave sería precisamente perder de vista la distinción elemental propuesta, lo que llevaría, lo que lleva en efecto a algunos, a correr sin rumbo, en distintas direcciones contradictorias, siempre detrás de lo último, que confunden con lo más avanzado, ya que no con lo más verdadero, por ser término y concepto éste tabú para ellos.

La voluntad de proceder de forma rigurosa, sistemática y objetiva ha sido temprana y persistente en la teoría literaria del siglo XX. Los forma-

\footnotetext{
${ }^{10}$ Apud Guillermo DE TORRE, Nuevas direcciones de la crítica literaria, Madrid, Alianza, 1970, p. 39.

${ }^{11}$ José-Luis García Barrientos, Cómo se comenta una obra de teatro: Ensayo de método [2001], Madrid, Síntesis, 2003², cap. 7, pp. 245-266.
} 
listas rusos se cuentan entre los primeros que intentan amoldarse a las exigencias del método científico. De ahí su preocupación por definir con rigor el objeto (la «literariedad») y el método («formal») de su estudio, sintomáticamente designado por ellos como «poética», «teoría»o «ciencia de la literatura», como denominaciones sinónimas.

Pero será sobre todo en las teorías estructuralistas y en algunas postestructuralistas —el «giro lingüístico» de la poética responde en buena medida a esta orientación- donde, bajo el influjo del positivismo lógico, se defienda la máxima adecuación de la investigación literaria a los requisitos del método científico; actitud que alcanza su grado extremo en la lingüística del texto $\mathrm{y}$, en particular, en Sigfried J. Schmidt con su proyecto de una ciencia empírica de la literatura ${ }^{12}$, quizás dependiente de las ciencias naturales en exceso y con excesiva utilización de técnicas estadísticas, sobre todo encuestas del tipo pregunta-respuesta.

Se podría incluso hablar, pero con cautela, de un proceso de convergencia en ambos sentidos ${ }^{13}$, pues también la filosofía de la ciencia, después de las teorías de Einstein, Heisenberg, etc., se acerca a los procedimientos de algunas ciencias humanas, particularmente quizás a los de la teoría literaria. Adquieren especial relevancia en este sentido las propuestas de Karl Popper: su defensa de la «unidad de método», la sustitución del principio de verificación por el de «falsación» y del concepto de objetividad por el de «intersubjetividad», su preferencia por los procedimientos deductivos, con el avance de hipótesis arriesgadas, susceptibles de falsación o de sanción intersubjetiva, etc.

$\mathrm{Y}$ es que en el interior de la propia ciencia se ha producido la subversión del esquema positivista de la verificación experimental de la teoría: los principios de «indeterminación» y de «complementariedad» (fenómenos idénticos admiten descripciones y explicaciones teóricas alternativas), juntos, implican una interferencia del observador o de la observación en el material fenoménico: mirar de cerca el mundo es ya alterarlo. Esta subversión epistemológica, tan sugerente para la estética y la hermenéutica, ha resultado, sin embargo, sólo marginalmente o en muy pequeña medida problemática en la práctica de las ciencias. Éstas proceden como si el contrato cartesiano-kantiano entre teoría y prueba siguiera siendo válido y universal. Y así parece que es, en términos de evidencia, excepto en ciertos límites extremos de la cosmología, o en la nueva física de la «singularidad». Los

${ }^{12}$ Véase su Fundamentos de la ciencia empírica de la literatura [1980], trad. de Francisco Chico Rico, Madrid, Taurus, 1990.

${ }^{13}$ Proceso que cuenta también con una dimensión histórica que valdría la pena poner en claro. Véase, por ejemplo, Esteban TORRE, Sobre lengua y literatura en el pensamiento científico español de la segunda mitad del siglo XVI: Las aportaciones de G. Pereira, J. Huarte de San Juan y F. Sánchez el Escéptico, Sevilla, Publicaciones de la Universidad de Sevilla, 1984. 
rendimientos de este proceder son manifiestos. El abandono de este concepto de teoría, de este pacto de reciprocidad entre teoría y hecho, cuyo fundamento último sigue siendo enigmático, sería considerado como el fin de la razón ${ }^{14}$.

En teoría literaria, la coexistencia de diferentes modelos heurísticos - frente a la sustitución de las teorías estrictamente científicas por otras de mayor capacidad explicativa - o el hecho de que tanto el objeto como el método varíen dependiendo del enfoque adoptado (literariedad y método formal para el formalismo ruso; estilo y método filológico o hermenéutico para la estilística, etc.), obliga a reconocer diferencias con los procedimientos de las ciencias exactas. Pero dicho eso, creo posible y hasta deseable la aspiración a, y el esfuerzo por, responder en nuestra disciplina a las exigencias del conocimiento científico, entendido en términos de rigor metodológico y de coherencia interna en el camino de ida y vuelta entre hipótesis teórica y verificación en los textos, lo que es compatible con una sana cautela ante actitudes extremosas o puramente subjetivas.

Más allá de la teoría literaria, de la deconstrucción, de la era postestructuralista o del posmodernismo, el trasfondo de la crisis epistemológica apenas esbozada es estremecedoramente más amplio y más grave, tal como lo ha descrito convincentemente George Steiner en Presencias reales. Se trata de la crisis del significado del significado o de la confianza en el lenguaje, la ruptura de la alianza entre la palabra y el mundo que se produce entre las décadas de 1870 y 1930 y que «constituye una de las pocas revoluciones del espíritu verdaderamente genuinas en la historia de Occidente y define la propia modernidad» ${ }^{15}$. Su magnitud puede calibrarse si pensamos que esta crisis cierra una primera fase de la cultura occidental, la del «logos», que va de los pre-socráticos a finales del siglo XIX, en la que hasta el escepticismo más extremo estaba comprometido - aceptaba el contratocon el lenguaje, y abre una segunda, de la post-palabra o el «epílogo».

Esta crisis encuentra ya expresión en la poesía autista de Mallarmé y en la estética de la autodestrucción de Rimbaud y se despliega en las siguientes revoluciones de la sensibilidad y el razonamiento: la filosofía del lenguaje (Frege, Russell, Wittgenstein), la lingüística moderna (postsaussureana: abstracta, formal), el psicoanálisis (Freud) y la crítica del lenguaje (Sprachkritik) de Fritz Mauthner. Principios implicados en esta crisis, que resultarán familiares a quien frecuente las últimas modas críticas, de la deconstrucción a los estudios culturales, son, por ejemplo, la abolición del sujeto, en particular del autor; la negación del acto de recepción como algo

${ }^{14}$ Cf. George STEINER, Presencias reales. ¿Hay algo en lo que decimos? [1989], trad. de Juan Gabriel López Guix, Barcelona, Destino, 1992², p. 92; fuente de la que literalmente bebo aquí y a cuya autoridad me remito.

15 Ibidem, p. 118. 
fiable; la ruptura de la relación entre ética y estética; el fin, por tanto, de la «responsabilidad»; en definitiva, el nihilismo.

De forma paradójica, hay que reconocer también, en el seno de esta profunda crisis del lenguaje, el lugar central que ocupa en el pensamiento filosófico del siglo XX precisamente el lenguaje, como pone de manifiesto Gadamer. La crítica de la autocerteza como fundamento de toda validez (Nietzsche, Freud, Heidegger) da paso a la consideración central de «el sistema del lenguaje que articula toda conciencia y todo saber». «El mundo intermedio del lenguaje aparece frente a las ilusiones de la autoconciencia y frente a la ingenuidad de un concepto positivista de los hechos como la verdadera dimensión de la realidad». Lo que ahora se indaga es «la enigmática relación que existe entre el pensar y el hablar». El lenguaje aparece así «como la mediación primaria para el acceso al mundo. Así se clarifica el carácter irrebasable del esquema lingüístico del mundo» ${ }^{16}$.

Aunque no podamos resolver un problema de tal envergadura aquí y ahora (y yo, desde luego, no puedo), es posible (y creo que se debe) tomar posición al menos frente a sus consecuencias en nuestros estudios, por comprometido que eso sea. Y ciertamente lo es.

Creo que la crisis epistemológica apenas evocada nos sitúa ante una alternativa ineludible entre el escepticismo radical, el relativismo «fundamentalista» o el nihilismo de las penúltimas corrientes críticas, de una parte, y de otra, una apuesta (a lo Pascal) por el sentido; entre el optimismo epistemológico, que, a pesar de las dificultades, prefiere creer que el hombre puede, en alguna medida, conocer la realidad, comunicar a otros su conocimiento y entender lo que otros le comunican, y el pesimismo que niega que sea posible conocer la realidad y tiene, por tanto, que concebir la comunicación como una cadena sin fin, a la deriva, de equívocos, despropósitos y sinsentidos.

Yo elijo con claridad el optimismo, apuesto por el sentido; aunque no alegremente, sino - es al menos lo que intento- de la manera más crítica, despierta o lúcida posible. Y tengo por falso el dilema que plantean a los estudios literarios en general y a la teoría en particular ciertos post-estructuralismos: o el escepticismo de Protágoras o el esencialismo de Platón. Falso, digo, porque creo que es posible una «tercera vía». Y creo que así lo entendió, hace más de veinticuatro siglos, Aristóteles. El «realismo» de su Poética, que no desconoce los datos empíricos pero construye sobre ellos modelos explicativos de racionalidad científica, me parece un ejemplo a tener en cuenta en la construcción de esa tercera vía. Que también puede beneficiarse de la contribución fundamental de Gadamer al conjunto de los es-

${ }^{16}$ Hans-Georg GADAMER, «Texto e interpretación» [1984], trad. de Manuel Olasagasti, en J. Domínguez CAPARrós (comp.), Hermenéutica, Madrid, Arco Libros, 1997 (pp. 77 114), p. 87. 
tudios humanísticos. Y que quiero creer que orientará el rumbo de la teoría en el futuro inmediato. De hecho, ya pueden advertirse algunos signos de ello, por ejemplo cuando en Estados Unidos se habla de la venganza de la estética ${ }^{17}$.

Del otro lado, el callejón sin salida a que han llevado los extremos del relativismo cognitivo a buena parte de los estudios deconstructivistas o posmodernos lo ilustra quizás mejor que largas discusiones el escándalo protagonizado por el físico de la Universidad de Nueva York Alan Sokal, con la publicación en la revista Social Text de su artículo «Transgrediendo los límites: Hacia una Hermenéutica transformativa de la gravedad cuántica»; que fue tomado en serio, cuando se trataba de una disparatada parodia de ese tipo de estudios. Tanto el affaire Sokal como la posterior tarea de denuncia de las imposturas intelectuales ${ }^{18}$ nos permiten proponer la modesta conclusión de que las ciencias humanas en general y la teoría literaria en particular deberían compartir con las ciencias propiamente dichas, por lo menos, los principios de racionalidad y de honradez intelectual.

\section{Post-estructuralismos: Tradición EUROPEA Y MODAS DE NOR- TEAMÉRICA}

Con las simplificaciones y generalizaciones que ya hemos asumido, intentaré primero dar una visión de conjunto, propedéutica pero comprometida, en primera persona, del estado actual de la teoría para detenerme luego en algunos aspectos característicos y prometedores de la misma. Para acotar en el tiempo el alcance de ese «actual» habrá que tomar como refe-

${ }^{17}$ Dejo constancia aquí de mi deuda, en lo que se refiere a este párrafo pero también a gran parte del epígrafe siguiente y a las líneas maestras de este ensayo, con un ciclo de tres conferencias que dictó Vitor Manuel de AgUiAR E SiLva, en la Facultad de Filología de la Universidad Complutense de Madrid, los días 26, 27 y 28 de noviembre del 2001, tituladas respectivamente: «Elegías y epitafios: Tanatografías contemporáneas de los estudios literarios», "Cartografías postestructuralistas del campo de los estudios literarios: Nuevos paradigmas, nuevas fronteras» y « Estudios literarios y estudios culturales: Balance y revisión de una comparación». No he encontrado la publicación del contenido de las mismas que prometió entonces el profesor portugués, lo que me impide documentar como es debido esa deuda que se desdibuja en la flaca memoria y en unas notas harto imprecisas; pero que sé grande, honda y muchas veces literal. Entre las reacciones más tempranas al relativismo hegemónico, hay que destacar la conferencia de apertura del Congreso Internacional de Germanística celebrado en Göttingen en 1985 que, con el título "“Sind eben alles Menschen gewessen”: Zum Kulturrelavismus in den Geisteswissenchaften», pronunció Ernst H. GOMBRICH («Relativismo en las humanidades: El debate acerca de la naturaleza humana», en Temas de nuestro tiempo: Propuestas del siglo XX acerca del saber y del arte, trad. de Mónica Rubio, Madrid, Debate, 1997, pp. 36-46).

18 Alan SOKAL y Jean BRICMONT, Imposturas intelectuales [1997], trad. de Joan Carles Guix Vilaplana, Barcelona, Paidós, 1999. 
rencia el punto en que deja de estar vigente el paradigma anterior en nuestros estudios.

Hablo de «paradigma» en el sentido ya clásico que le dio Kuhn ${ }^{19}$, es decir, como las herramientas de conocimiento que la comunidad profesional acepta en un momento dado para la indagación de un saber. Es sabido que el propio Kuhn ha reconocido las ambigüedades del concepto y ha propuesto, sin éxito, sustituirlo por «matriz disciplinar». Y es cierto también que se ha hecho un uso excesivo y trivializante de él en las ciencias humanas, con la pretensión muchas veces de conseguir un barniz de legitimación científica.

En teoría, unos paradigmas son sustituidos por otros, que los superan (y los integran a veces); en la realidad, el proceso es más complejo y confuso, con avances y retrocesos e indecisiones antes de que una forma se imponga como triunfadora. La caída de un paradigma puede provocar turbulencias, corrimientos, movimientos de dispersión y fenómenos de inestabilidad en el área de conocimiento de que se trate, hasta que se impone, si es el caso, un nuevo paradigma.

Precisamente una situación postparadigmática de este tipo es la que vive la teoría literaria desde hace tres décadas aproximadamente, desde los años setenta, en los que todavía se proyecta la sombra poderosa del paradigma anterior, hasta hoy. Si hubiera que cifrar en una fecha este cambio, no dudaría en proponer el año 1968, tan cargado de significados y con cuyo «espíritu» tiene mucho que ver lo sucedido hasta ahora en nuestra disciplina. Alrededor de ese año se producen los primeros escritos del grupo de Constanza, en los que parece haber entrado definitivamente en crisis el paradigma de la función poética o de la «literariedad». De un año antes es, además del célebre discurso de Jauss ${ }^{20}$, La escritura y la diferencia de Derrida $^{21}$, y de un año después, La arqueología del saber de Foucault ${ }^{22}$, nombres decisivos para el cambio de rumbo de la teoría.

El paradigma anterior domina toda la primera mitad larga del siglo XX y suele denominarse «formalista-estructuralista», aunque entre los dos términos existen divergencias no despreciables: René Wellek afirma en sus Conceptos de crítica literaria que sería fácil reunir un centón de definicio-

19 Thomas S. Kunn, La estructura de las revoluciones científicas [1962], México, Siglo XXI, 1978.

${ }^{20}$ Hans Robert JAUSS, «La historia literaria como desafío a la ciencia literaria» [1967], en H. U. Gumbrecht y otros (eds.), La actual ciencia literaria alemana: seis estudios sobre el texto y su ambiente, trad. de H. U. Gumbrecht y Gustavo Domínguez León, Salamanca, Anaya, 1971, pp. 37-114.

21 Jacques DERRIDA, La escritura y la diferencia [1967], trad. de Patricio Peñalver, Barcelona, Anthropos, 1989.

${ }^{22}$ Michel Foucault, La arqueología del saber [1969], trad. de Aurelio Garzón del Campo, Barcelona, Siglo XXI, 1972, $1995^{16}$. 
nes de «forma» y «estructura», todas contradictorias ${ }^{23}$. Se extiende del formalismo ruso y luego checo al estructuralismo francés y se pueden asimilar a él, con matices que no caben aquí, otras grandes escuelas del periodo, como la estilística ${ }^{24}$, la poética morfológica alemana, la nueva crítica angloamericana y hasta la fenomenología literaria (Ingarden). Común a todas estas corrientes es considerar posible una ciencia de la literatura (frente al impresionismo), tomar como modelo la lingüística (en particular la saussureana y estructuralista) y practicar el análisis inmanente.

Se trata de un paradigma antihegeliano, que rechazó el historicismo y también el positivismo del XIX, el marxismo y, en general, el sociologismo. Sus aportaciones son de una consistencia y han supuesto un avance tal de la teoría literaria que resulta difícil encontrarles parangón. Su manifestación más genuina me parece la narratología — sobre todo tal como la construye Genette-, que sobrevive a la quiebra del paradigma y resulta hoy mismo tan vigente como imprescindible.

Pero desde el principio mismo, en el Formalismo ruso, el paradigma se vio afectado por el conflicto, por ejemplo entre sincronía y diacronía; su estabilidad y pervivencia han sido amenazadas por teorías como las de Bajtín o Sartre, por ejemplo; sus fundamentos, corroídos por el pluralismo hermenéutico de Gadamer desde principios de los años 60; a finales, la crítica de Derrida, verdadero caballo de Troya de este paradigma, terminó por minarlo. A partir de su disgregación se abren los nuevos horizontes teóricos del llamado post-estructuralismo, que presenta la forma de un variado archipiélago, con islas o corrientes más o menos vistosas y más o menos fértiles, que tienen en común sobre todo la referencia al paradigma anterior como punto de partida. La misma denominación, que sería preferible usar siempre en plural, lo pone de manifiesto.

En este sentido, el post-estructuralismo nace y se desarrolla en el seno del estructuralismo: Barthes, Lacan, Foucault han sido, en cierto modo, estructuralistas y post-estructuralistas a la vez, casi simultáneamente. Se da el caso de que la antología que introdujo el estructuralismo en Norteamérica contenía precisamente un artículo de Derrida, con el que se dio a conocer en los Estados Unidos y en el que hacía una crítica del concepto estructuralista de estructura ${ }^{25}$.

De la ambigüedad del prefijo «post», que puede significar a la vez continuidad y corte, herencia y diferencia, me parece útil subrayar el contraste entre estos dos polos. En el de la diferencia, el término «post-estructuralis-

${ }^{23}$ Apud G. DE TORRE, op. cit., p. 126.

${ }^{24}$ Véase José María Paz Gago, La estilística, Madrid, Síntesis, 1993.

25 J. DERRIDA, «Estructura, signo y juego en el discurso de las ciencias humanas», en R. MACKSEY y E. Donato (eds.), Los lenguajes críticos y las ciencias del hombre: Controversia estructuralista [1970], trad. de José Manuel Llorca, Barcelona, Barral, 1972, pp. 269-287 («Discusión», pp. 287-293). 
mo» designa un amplio abanico de discursos teóricos — con la deconstrucción ocupando, paradójicamente, un lugar central- que coinciden en abandonar el proyecto estructuralista de investigar la significación de los fenómenos culturales, es decir, qué los hace comprensibles, para aplicarse a la crítica del saber como conocimiento objetivo, a la crítica del sujeto como capaz de conocerse a sí mismo y a la crítica de la totalidad: imposibilidad de describir un sistema completo y coherente, pues tales sistemas están en permanente cambio. Pero el campo de la teoría después del estructuralismo incluye también corrientes que pueden más o menos legítimamente considerarse herederas de aquél, que pretenden superar el paradigma anterior, pero integrándolo de alguna forma (pienso, por ejemplo, en la teoría de los polisistemas de Even-Zohar). Estas últimas son seguramente predominantes en la teoría europea (continental), mientras que las otras, más «críticas», caracterizan más la teoría norteamericana. Gran Bretaña, como siempre, se mueve entre dos aguas, un poco más quizá del lado americano que del europeo.

Para apreciar las diferencias que presenta la teoría en Norteamérica y en Europa, bastará reparar en la relación de las escuelas y corrientes postestructuralistas que hace Culler:

Deconstrucción, Teoría feminista, Psicoanálisis, Marxismo, Nuevo historicismo y Materialismo cultural, Teoría poscolonial, Discurso de las minorías (Multiculturalismo) y Teoría gay (Queer theory) ${ }^{26}$.

Y compararla, por ejemplo, con los programas de la asignatura en las universidades españolas; o con la lista que encontramos en otra Introducción, europea y más reciente, la de Miguel Ángel Garrido Gallardo:

Temática, Semiótica, Lingüística textual, Pragmática, Retórica, Estética de la recepción, Hermenéutica, Deconstrucción, Sociocrítica (marxista y posmarxista), Teorías sistémicas y Psicocrítica ${ }^{27}$.

Generalizando, podríamos sintetizar el panorama norteamericano en estas tres modas teóricas: $1^{\mathrm{a}}$ ) la de una crítica epistemológica, es decir, de los principios básicos: el lenguaje, la representación, el pensamiento crítico (deconstrucción, psicoanálisis); $2^{\mathrm{a}}$ ) la de una crítica del papel del género y la sexualidad (feminismo, teoría de «género», teoría gay); y $3^{\text {a }}$ ) la de una crítica cultural de orientación histórica y social «nueva» (nuevo historicismo, teoría poscolonial, marxismo) ${ }^{28}$.

De la parte europea, se puede advertir: $1^{\circ}$ ) la confluencia de corrientes

${ }^{26}$ Jonathan CULLER, Breve introducción a la teoría literaria [1997], trad. de Gonzalo García, Barcelona, Crítica, 2000, pp. 150-157.

${ }^{27}$ Nueva introducción a la teoría de la literatura [2000], Madrid, Síntesis, $3^{\text {a }}$ ed. corregida y aumentada, 2004, pp. 80-83.

28 J. CULler, op. cit., p. 145. 
en torno a la dimensión comunicativa, discursiva o, si se quiere, retórica de la teoría (semiótica, teoría del texto, pragmática); $2^{\circ}$ ) la atención preferente al polo de la recepción o la operación de la lectura (estética de la recepción, hermenéutica, deconstrucción); y $3^{\circ}$ ) la vertiente histórica y cultural, de base sociológica, que está presente en las teorías sistémicas, tanto la empírica de Schmidt como la de los polisistemas de Even-Zohar; en las inspiradas en Bajtin o en Lotman y la escuela de Tartu, de raíz más o menos marxista; también las que, superado el marxismo, siguen tomando como clave la sociología (por ejemplo de Bourdieu). La psicocrítica se mantiene vigente sobre todo en la «poética de lo imaginario», de orientación antropológica; el psicoanálisis parece haber perdido casi todo su predicamento.

Es curioso, o mejor sorprendente, que sea precisamente en Estados Unidos y en Gran Bretaña donde marxismo y psicoanálisis hayan encontrado una especie de nueva vida después de la crisis (el descrédito) de cada uno en el viejo continente. No sé si la perplejidad desaparece o aumenta al advertir que se emplean ahora como teorías «débiles», sin las pretensiones totalizadoras o la ambición epistemológica que los caracterizaban en su desarrollo paralelo al paradigma anterior. Se puede, generalizando, señalar como característico de los post-estructuralismos una crisis de las teorías «fuertes», que pretenden ofrecer una explicación total de lo literario, como parte de una totalidad más amplia todavía; modelo al que responden no sólo el marxismo y el psicoanálisis, sino también el estructuralismo, con sus propios marcos totalizantes: lingüístico, antropológico, etc. No puedo disimular la impresión de que las aportaciones a la comprensión de la literatura que se han hecho desde aquellas teorías fuertes son incomparablemente más fecundas y consistentes que las que se vienen haciendo, hasta ahora, digamos, a la contra. Tampoco que la renuncia a esta clase de ambiciones, tal vez desmesuradas, lleve aparejado algo de renuncia a la propia y genuina «teoría» sin más.

Pero quizás la nota más característica y preocupante de las últimas tendencias o modas, sobre todo en Norteamérica, sea la pérdida de la especificación literaria de nuestra disciplina, que deja de ser teoría de la literatura para convertirse en teoría a secas. El ámbito literario, que suele ser el punto de partida, tiende a ser rebasado, para ampliarse primero la teoría hasta ser «de la literatura y de la cultura» y convertirse luego cada vez más en teoría -y sobre todo en crítica-cultural. En Europa, creo, el ámbito de la teoría literaria está más o mejor delimitado, goza de mayor autonomía, por lo menos hasta ahora.

Si nos empeñamos en ver el lado positivo de cualquier cosa, podríamos ponderar las ventajas de la interdisciplinariedad; que para la teoría literaria es sencillamente imprescindible pues vive o se alimenta de ella. ¿Cómo podría eludir contaminarse de lingüística, de filosofía, de sociología, de psicología, etc.? Pero no se puede ocultar que este impulso hacia la 
confusión con la crítica cultural (militante) y enseguida política, todo lo loable que se quiera, sitúa la teoría literaria en el despeñadero hacia su disolución como tal. No se anda lejos de ello, me parece, cuando predomina, como en la teoría americana sobre todo, no sólo la hermenéutica de la sospecha, centrada en los supuestos ocultos (políticos, sexuales, filosóficos) del texto literario, sino también y sobre todo la interpretación que llama Culler «sintomática» ${ }^{29}$, es decir, la que trata el texto como síntoma de algo no textual, supuestamente más profundo y la razón auténtica de su interés - la psique del autor, la homofobia de la sociedad burguesa, etc.- y niega, por tanto, lo específico del texto literario, que se reduce a indicio de otra cosa.

Pero esta crisis de autonomía va más allá de la teoría. Son los estudios literarios en general los que parecen disolverse en los emergentes «estudios culturales» (cultural studies) — por cierto nacidos también en Europa o por lo menos en Gran Bretaña-, que se caracterizan precisamente por atender a lo que quedaba casi siempre fuera del canon literario, como la literatura popular, la televisión, el cine, los contextos sociales, etc.; pero seguramente mucho más en Norteamérica que en Europa ${ }^{30}$. Y, en definitiva, es la literatura misma la que sufre esta crisis de autonomía o de identidad. En palabras de Alan Liu, la literatura «es una categoría que ha perdido progresivamente su especificidad en el plano indiferenciado del "discurso" cultural, de la "textualidad", de la "información"» y los estudios culturales hacen de ella «un registro equipolente más de la cultura y de la multicultura, ni más ni menos espléndido que las prácticas diarias de vestirse, caminar, cocinar o hacer la cama» ${ }^{31}$.

Soy capaz de valorar las consecuencias positivas de una crisis tan profunda de la literatura y de la teoría y de celebrar el nuevo dinamismo que puede suponer para ésta verse empujada fuera de su particular campo de acción y arrojada al centro del debate de las humanidades, del canon literario y, en fin, de la crítica y la política cultural. Pero no hasta el extremo, que algunos entusiastas de lo último (en exclusiva) parecen propugnar, de abandonar como obsoleto ese campo propio de la teoría literaria, que es el campo de la literatura y sus problemas; problemas de género, de métrica, de interpretación, etc., que siguen obstinadamente ahí, asistiendo a la sucesión de avatares o modas de la teoría; y de los que habrá que ocuparse - digo yo- también.

Entre los últimos perfiles de la teoría actual se puede hablar de un cierto

${ }^{29}$ Ibidem, p. 86.

${ }^{30}$ Apocalípticos e integrados ante la cultura de masas, de Umberto ECO, es de 1965 (trad. de Andrés Boglar: Barcelona, Lumen, 1968), por ejemplo.

${ }^{31}$ Cit. en J. Hillis MiLler, «¿Sobrevivirán los estudios literarios a la globalización de la universidad y al nuevo régimen de las telecomunicaciones?», trad. de Mabel Richart, Prosopopeya, 1, 1999 (pp. 71-90), p. 72. 
narcisismo metateórico (sin ningún matiz peyorativo) que consiste en un desplazamiento del centro de interés desde el circuito de la comunicación literaria hacia la relación (externa) de éste con los sujetos que la estudian, más en la dimensión social o institucional que individual. No importa tanto el sentido o los sentidos de la obra literaria cuanto el «lugar» de la teoría, la función histórica y social de los teóricos; no tanto quienes leen o escriben la literatura cuanto quienes la trabajan o administran, quienes sancionan textos e interpretaciones. De ahí la importancia que cobra el control institucional de la interpretación ${ }^{32}$ y el debate sobre el canon ${ }^{33}$. Todo ello supone un desplazamiento de la teoría hacia los aspectos políticos e institucionales de su propia constitución. El lugar central del debate corresponde al «campo» de la teoría como lugar epistemológico y político ${ }^{34}$. Cobra especial relevancia así la vertiente pedagógica, la cuestión de la enseñanza, que ha desencadenado las llamadas «guerras de la cultura» en Estados Unidos entre liberales y conservadores o izquierdas y derechas.

A pesar de las diferencias señaladas, es muy notable el influjo de la teoría norteamericana en la europea, en gran medida también como fenómeno de moda, que salta por encima de las diferencias de realidad. Pues la norteamericana es una sociedad multirracial y multicultural cuya literatura nacional ha sido la de otra nación, Inglaterra; con la chocante anomalía, pues, de que hasta hace muy poco la educación en los valores nacionales se basaba en la literatura de un país extranjero que había sido vencido doscientos años antes en una revolucionaria guerra de independencia ${ }^{35}$. En esa situación, muy distinta de la de las viejas naciones europeas como España y de las nuevas como Alemania o Italia, es en la que cobran pleno sentido las guerras de la enseñanza y el debate sobre el canon.

También las condiciones de la institución literaria norteamericana, en particular de la universidad, son peculiares e influyen en las orientaciones de la teoría. Muy decisivo resulta el enfrentamiento entre los departamentos de literatura inglesa, en los que siguen siendo hegemónicos los principios del New Criticism, y los de literatura comparada, a los que queda relegada la teoría, que sufre un desarraigo tradicional allí. Como reacción a ese estado de cosas se explica la virulencia del debate y el radicalismo cultural de la nueva teoría norteamericana; por ejemplo, su preferencia por

${ }^{32}$ Véase Frank KERMODE, «El control institucional de la interpretación» [1979], trad. de la revista Saber, en E. Sullà (comp.), El canon literario, Madrid, Arco Libros, 1998, pp. 91-112.

${ }_{33}$ Véase, además del volumen citado en la nota anterior, José María Pozuelo Yvancos y Rosa María ARADRA SÁNCHEZ, Teoría del canon y literatura española, Madrid, Cátedra, 2000.

${ }^{34}$ Véase Wlad Godzich, Teoría literaria y critica de la cultura [1994], trad. de JosepVicent Gavaldà, Madrid, Cátedra, 1998 (pp. 331 y ss. para la cuestión del «campo»).

${ }^{35}$ Cf. J. Hillis Miller, art. cit., p. 77. 
los modelos (europeos, por cierto) más críticos y antisistemáticos: por Derrida o Foucault, y no por Jauss o Lotman.

Y en clave política, la rareza de la carga ideológica de la teoría, de su carácter subversivo, de su reivindicación de las diferencias en un contexto general de globalización y crepúsculo de las ideologías, tiene que ver sin duda con una especie de respuesta al rearme ideológico de la época de Reagan (y de Thatcher en Gran Bretaña) y también con los avatares - la nostalgia o la revancha- de la generación que vivió los hechos y el espíritu, la ilusión y la desilusión del 68 .

Otro factor de transformación de los estudios literarios, y por tanto de la teoría, a la vez que de su objeto mismo, la literatura, es el de las nuevas tecnologías de la comunicación, en particular la revolución digital, que ha abierto un proceso que parece irreversible. Precisamente a este asunto dedicó la Asociación Española de Teoría de la Literatura (ASETEL) su segundo Simposio (2001), en la Universidad de Zaragoza. Nuestros modos, hábitos y herramientas de trabajo han sido ya profundamente modificados por el ordenador y la red, y lo serán previsiblemente más ${ }^{36}$. Puede que menos evidente, y acaso más profunda, será la transformación de la literatura misma, de la manera de escribirla y de leerla, de producirla y de consumirla, por el nuevo régimen de las telecomunicaciones.

La aparición del cibertexto tendrá seguramente a la larga consecuencias tan importantes como las de otros cambios experimentados históricamente en el modo de existencia del objeto literario, cuyos hitos más decisivos han sido la escritura y la imprenta. Ya se pueden advertir algunos efectos de alcance, como el debilitamiento o la desaparición de la distinción entre texto e imagen, por ejemplo, o, todavía más grave para lo «literario», entre ficción y realidad. Según Hillis Miller: «La oposición neta entre la ficción y la verdad es un rasgo propio de la cultura impresa. En el mundo globalizado de Internet, la distinción se rompe o resulta transformada, tal y como resulta ya transformada por la televisión» ${ }^{37}$.

Para atemperar un poco la magnitud del impacto de las innovaciones tecnológicas en la literatura misma y poner coto a entusiasmos excesivos o prematuros conviene no perder de vista el referido «orden simultáneo» (presentness) que la caracteriza. Bastará, por ejemplo, comparar el progreso tecnológico de la humanidad en los últimos dos milenios y medio con el no-progreso del arte del dramaturgo desde Esquilo hasta hoy mismo;

\footnotetext{
${ }^{36}$ Síntoma del interés por este asunto es la reciente aparición en una de las colecciones destacadas al principio de dos antologías: Domingo SÁNCHEZ-MESA MARTínEZ (comp.) Literatura y cibercultura, Madrid, Arco Libros, 2004; M. ${ }^{a}$ Teresa VILARIÑO Picos y Anxo Abuín GonZÁlez (comps.), Teoría del hipertexto: La literatura en la era de la electrónica, Madrid, Arco Libros, 2006.

37 Art. cit., p. 83.
} 
alusión que me hace recordar unas palabras de Kadaré que vale la pena traer a colación, no como refutación sino como contrapunto:

La literatura antigua es tan sorprendente en lo relativo a la técnica de escritura como en todo lo demás. Cuando penetramos en su mundo, advertimos lo ingenuo de tesis como la de la supuesta influencia que han ejercido sobre la técnica de escritura las innovaciones tecnológicas, ante todo las vinculadas con la celeridad de los medios de transmisión o de transporte: la radio, el teléfono, la televisión, la aviación, los vuelos espaciales, etcétera. Según las exiguas mentes que lo sostienen, este influjo es tan notable que podría transformar la propia naturaleza de la literatura. Para apreciar lo frívolo de tal tesis, basta con que leamos el principio de la Ilíada; el gran ciego no tuvo necesidad de clase alguna de ondas televisivas o de naves espaciales para mover la cámara desde los territorios celestes, más precisamente desde el colérico cerebro de Zeus, hasta abajo en la tierra, al campamento militar desplegado frente a Troya, y después sobre las cabezas dormidas de los miles de soldados y comandantes, hasta dar con el cráneo de Agamenón, en cuyo interior fermenta un ensueño ${ }^{38}$.

Como conclusión de este somero repaso, propongo volver los ojos a una constatación empírica tan sencilla como elocuente: el hecho de que, afortunadamente, a pesar de todo, sigue habiendo - y cada vez más- quienes escriben poemas, narraciones o dramas con entusiasmo, y quienes los leen con fruición. Mientras esto sea así, tendremos literatura, y teoría, para rato. Y las elegías y los epitafios que se dediquen a una y a otra no serán, afortunadamente, más que eso: literatura.

\section{El imPERIO DE LA LECTURA: HeRMENÉUtica y ReCEPCIÓN}

Una de las señas de identidad de la teoría literaria actual es el sesgo hermenéutico, que explicaba así David Lodge:

En los últimos años, el centro de interés se ha desplazado del intento estructuralista de analizar los discursos, incluidos los textos literarios, en función de los sistemas de significación de los que son manifestaciones, al problema de la lectura, de la interpretación. Pero esta nueva hermenéutica está impregnada de un básico escepticismo acerca de la posibilidad de recuperar para el discurso un significado fijo y estable ${ }^{39}$.

José Domínguez Caparrós, de quien tomo la cita, plantea certeramente cómo y en qué medida puede la tradición hermenéutica contribuir en la

${ }^{38}$ Ismaíl KADARÉ, Esquilo: El gran perdedor [1985-2000], trad. de Ramón Sánchez Lizarralde y María Roces, Madrid, Siruela, 2006, pp. 233-234.

39 «Después de Bakhtin» [1987], en N. FABB y otros (comps.), La lingüística de la escritura: Debates entre lengua y literatura, trad. de Javier Yagüe Bosch, Madrid, Visor, 1989 (pp. 97-109), p. 98. 
actualidad a la teoría literaria ${ }^{40}$. Nos recuerda el gran impacto que en el ámbito anglosajón tienen ya en los años setenta y ochenta importantes obras y debates sobre hermenéutica ${ }^{41}$ : basta pensar en los nombres de E.D. Hirsch Jr., S. Fish o M.H. Abrams.

Es evidente la relación de la hermenéutica con líneas post-estructuralistas como la pragmática (centrada en la relación signo-intérprete), la estética de la recepción, en cuya prehistoria habría que situar, según Jauss, la interpretación clásica de Homero y la exégesis bíblica ${ }^{42}$, y corrientes críticas como la feminista y desde luego la deconstrucción: pensemos en Paul de Man o en Derrida, con Heidegger al fondo.

El giro hermenéutico de la teoría literaria reciente permite a ésta volver a encontrarse con la filosofía (de Platón a Schleiermacher, Dilthey, Heidegger y Gadamer), encuentro por el que tanto y tan brillantemente ha hecho entre nosotros Emilio Lledó ${ }^{43}$. De más alcance aún es este giro según Gianni Vattimo, que considera la hermenéutica como la nueva koiné - el idioma común - de la filosofía o, en sentido más amplio, de la cultura de los años ochenta, como habían sido antes el marxismo, en los cincuenta y sesenta, y el estructuralismo, en los setenta ${ }^{44}$.

En la teoría literaria actual, la mayor parte de las disciplinas interpretativas se mueven en el marco anti-intencionalista, cuya fuente más próxima es sin duda el estructuralismo. Estas prácticas hermenéuticas pueden adoptar tres formas distintas. La primera reduce la intencionalidad «superficial» a representaciones inconscientes subyacentes, inaccesibles al autor y accesibles sólo con los instrumentos analíticos privilegiados, sean los del psicoanálisis o los de varios tipos de interpretación ideológica, como los que remiten a estrategias de clase o a la voluntad de poder, por ejemplo ${ }^{45}$.

40 «Teoría literaria y tradición hermenéutica», Prosopopeya, 1, 1999, pp. 27-47. Véase José Manuel Cuesta ABAD, Teoría hermenéutica y literatura: El sujeto del texto, Madrid, Visor, 1991; Ficciones de una crisis: Poética e interpretación en Borges, Madrid, Gredos, 1995.

${ }^{41}$ Remito a las introducciones de su libro Orígenes del discurso crítico. Teorías antiguas y medievales sobre la interpretación, Madrid, Gredos, 1993 (p. 8, n. 1 y pp. 1920) y de su antología Hermenéutica, cit., pp. 7-17.

${ }^{42}$ H. R. JAUSS, «The theory of reception: a retrospective of its unrecognized prehistory» [1990], en P. COLLIER y H. GEYER-RYAN (eds.), Literary Theory Today, Oxford, Polity Press, 1992 (pp. 53-73), p. 54.

${ }^{43}$ Véanse, por ejemplo, «Literatura y crítica filosófica», en J. M. DíEz BoRQuE (ed.), Métodos de estudio de la obra literaria, Madrid, Taurus, 1985, pp. 419-463; El silencio de la escritura, Madrid, Centro de Estudios Constitucionales, 1991; El surco del tiempo. Meditaciones sobre el mito platónico de la escritura y la memoria, Bercelona, Crítica, 1992.

${ }^{44}$ Gianni VAtTimo, Ética de la interpretación [1989], trad. de Teresa Oñate, Barcelona, Paidós, 1991, p. 95.

${ }_{45}$ Véase Fredric JAMESON, Documentos de cultura, documentos de barbarie: La narrativa como acto socialmente simbólico [The Political Unconscious, 1981], trad. de Tomás Segovia, Madrid, Visor, 1989. 
La segunda, más profunda, reduce la intencionalidad a una expresión de factores causales no intencionales. La «teoría del reflejo» es un ejemplo acabado: no se trata ahora de «estar al servicio» de una clase inconscientemente, sino de «ser producido» por un estado social determinado. La interpretación marxista suele combinar estos dos reduccionismos. La tercera forma consiste, radicalmente, en negar la pertinencia de la noción de intencionalidad misma y va ligada a la tesis del carácter indeterminado de la significación, y se identifica sobre todo con la crítica deconstruccionista, con Derrida y Paul de Man a la cabeza.

Es fácil advertir el carácter auto-refutante del anti-intencionalismo radical: si la significación de un texto no es la del autor, sino la que le da el lector, también se podrá aplicar a quien formula esta tesis... Este callejón sin salida no tiene otra - tan transitada, sobre todo por la «teoría de los actos de lenguaje», como problemática- que segregar los textos literarios, afectados de esa indeterminación significativa, de los demás; lo que, han notado algunos ${ }^{46}$, supondría una vuelta —inesperada - a las definiciones esencialistas.

Ya tomé partido de forma muy general en uno de mis libros ${ }^{47}$ ante los distintos «modelos» hermenéuticos ${ }^{48}$, como resumo brevemente a continuación:

De la hermenéutica positiva o de la restauración, de raíz decimonónica y de carácter historicista e idealista, centrada en la intentio auctoris, no creo que se puedan aceptar sus pretensiones de exclusividad (una única y difícil interpretación «literal» determinada por el contexto de gestación y las intenciones del autor), pero sí que se debe estimar la contrastada solidez y eficacia de sus métodos (los más científicos — para bien y para mal- en la investigación literaria) y, desde luego, no ignorar sino tomar en consideración sus conclusiones. La utilidad de la erudición filológica o histórica me parece indiscutible; pero como condición necesaria, no suficiente.

Con la hermenéutica negativa o de la sospecha, centrada en la intentio lectoris, de la que es manifestación radical la deconstrucción, se puede compartir el carácter abierto (hacia el lector) de la interpretación, pero no la negación de cualquier límite a esa apertura, es decir, de cualquier procedimiento de decisión razonable o refutable para elegir entre un sinfín de interpretaciones o modelos, ni mucho menos una libertad de interpretación que ampare el puro capricho o la arbitrariedad de «una lectura libre donde

${ }^{46}$ Véase Stanley Fish, Is There a Text in this Class? The Authority of Interpretative Communities, Cambridge (Mass.), Harvard University Press, 1980.

${ }^{47}$ Cómo se comenta..., cit., pp. 23-24.

${ }^{48}$ Cf. César Nicolás, «Entre la deconstrucción», en M. ASENSI (comp.), Teoría literaria y deconstrucción, Madrid, Arco Libros, 1990, pp. 307-338. 
la voluntad de los intérpretes, para usar la metáfora de Rorty, sacude los textos hasta darles la forma que sirva a sus propósitos» ${ }^{49}$.

Es la hermenéutica de la integración, que intenta compaginar la intentio operis y la intentio lectoris, sin abandonar - aunque revisando- la intentio auctoris, con sus hitos en la obra de Gadamer ${ }^{50}$ y Ricoeur ${ }^{51}$, la dirección que parece más fecunda y la más congruente con la orientación de los estudios literarios desde los años setenta, por lo menos en Europa. Se trata de concebir la interpretación como un proceso en el que intervienen el autor, el texto y el lector sumergidos en la historia, y en el que se impone el diálogo, la relación interactiva entre el mundo presente del intérprete y el mundo pasado (original) de la obra, tamizado éste por la tradición histórica de sus recepciones; es decir, de una hermenéutica de raíz semiótica y pragmática, que atiende a todos los factores integrantes del proceso comunicativo, incluido el contexto histórico.

Un autor que destaca precisamente el carácter retórico y político de la interpretación, Steven Mailloux, apunta la posibilidad de elaborar lo que denomina «teorías de los principios neutros» y concibe como un conjunto de reglas formalistas (basadas en el texto) e intencionalistas que se aplican de forma «neutra», es decir, desinteresada, no subjetiva y sin prejuicios políticos ${ }^{52}$. También considero interesante y útil la tarea de seguir perfilando una serie de distinciones conceptuales, que las estrategias interpretativas anti-intencionalistas omiten, pero en la que no pueden dejar de basarse, como no pueden dejar de presuponer siempre una comprensión digamos «común» del texto. Por ejemplo, la que establece Hirsch entre significación y sentido ${ }^{53}$. O entre comprensión e interpretación. Y en ésta, a su vez, entre interpretación superficial e interpretación profunda ${ }^{54}$.

Todo ello sin negar graves límites que parecen inherentes a la actividad hermenéutica. Por ejemplo, la imposibilidad de constituirse como operación inmanente al texto, o la necesidad de presuponer un trasfondo de conocimientos culturales (históricos, sociales, literarios), que entran en una peligrosa relación de circularidad con los textos mismos (en los que a su vez se basan esos conocimientos). Y, todavía más grave, el de no poder

49 Umberto ECO, Los límites de la interpretación [1990], trad. de Helena Lozano, Barcelona, Lumen, 1992, p. 370.

50 Verdad y método. Fundamentos de una hermenéutica filosófica [1960], trad. de Ana Agud Aparicio y Rafael de Agapito, Salamanca, Sígueme, 1977.

51 Paul RiCOEUR, Le conflict des interprétations. Essais d'herméneutique, París, Seuil, 1969; La métaphore vive, París, Seuil, 1975; Du texte à l'action, París, Seuil, 1986.

52 Steven MaILlOUX, «Interpretación» [1990], trad. de Antonio Ballesteros González, en J. Domínguez Caparrós (comp.), Hermenéutica, cit., pp. 159-180.

53 E.D. HiRSCH, Jr., Validity in interpretation, New Haven, Yale University Press, 1967.

${ }^{54}$ Cf. Arthur C. DAnTo, The Pphilosophical Disenfranchisement of Art, Nueva York, Columbia University Press, 1986. 
rebasar el estatuto de probabilidad al reconstruir la significación de un texto, por no tener nunca acceso directo a los estados intencionales expresados en él. Y esto no sólo en lo que se refiere a los textos literarios, a cuyas peculiaridades - ficción, poeticidad, etc.- habrá que prestar especial atención, ni siquiera a los textos escritos, sino seguramente a cualquier manifestación del lenguaje.

Junto a la hermenéutica, y estrechamente relacionadas con ella, habría que recordar en esta orientación de la teoría que privilegia la operación de la lectura por lo menos la «estética de la recepción» de la escuela de Constanza y la «crítica de la respuesta del lector» anglosajona, que nacen de una crítica tanto de la historia literaria tradicional como del análisis formalista.

La estética de la recepción ha renovado profundamente la historia literaria, sobre todo al abordar frontalmente la cuestión de la interpretación histórica de los textos y al introducir el concepto de «horizonte de expectativas». Sus limitaciones metodológicas, que proceden seguramente de sus orígenes en la hermenéutica «textual», reclaman una apertura hacia el estudio empírico - estrictamente histórico - de las prácticas de lectura efectivas, en la medida en que se puedan reconstruir; o hacia la orientación antropológica, en la línea de los trabajos más recientes de Iser ${ }^{55}$. El libro de Enrique García Santo-Tomás sobre Lope de Vega ${ }^{56}$, por ejemplo, pretende ensanchar los límites de la estética de la recepción con otros enfoques, como los del sociólogo Pierre Bourdieu. Por otra parte, la estética de la recepción es compatible también con el formalismo, por ejemplo cuando se privilegia casi exclusivamente el plano formal de la lectura, como hace Riffaterre ${ }^{57}$.

La «crítica de la respuesta del lector» engloba en realidad un conjunto de enfoques (fenomenológico, estructural, retórico, deconstructivista) que coinciden sólo en centrarse en el proceso de lectura, bien de lectores singulares (N. Holland), bien de comunidades de lectores con estrategias comunes (S. Fish, J. Culler). Incluye actitudes que van de considerar las respuestas de los lectores en gran parte regidas por las convenciones textuales (Culler) a considerarlas como «equivalente» del texto (Fish). Si es cierto que disuelve la obra en la referencia al lector, al menos sigue concibiéndola como una estructura de pregunta y respuesta y se basa en un modelo de comunicación literaria, que supone, por cierto, la posibilidad de acceder a una intención autorial ${ }^{58}$.

\footnotetext{
${ }^{55}$ Por ejemplo, Wolfgang ISER, «La ficcionalización: Dimensión antropológica de las ficciones literarias» [1990], trad. de Paloma Tejada Caller, en A. GARRIDO DOMínGUEZ (comp.), Teorías de la ficción literaria, Madrid, Arco Libros, 1997, pp. 43-65.

${ }^{56}$ La creación del «Fénix». Recepción crítica y formación canónica del teatro de Lope de Vega, Madrid, Gredos, 2000.

${ }_{57}$ Michel Riffaterre, La production du texte, París, Seuil, 1979.

58 Véase S. MaIlloux, Interpretative Conventions. The Reader in the Study of American Fiction, Ithaca, Cornell University Press, 1982.
} 
Tratándose de un punro de vista fecundo y legítimo, me parece claro que ni el análisis de las obras ni la historia literaria se pueden reducir a una historia de sus recepciones o lecturas: ésta presupone un algo que se lee o se recibe, y que también se crea o se produce.

\section{A VUELTAS CON LA Historia}

El paradigma formalista-estructuralista, ya lo hemos dicho, es profundamente antihegeliano. Las corrientes más importantes y fecundas de la teoría literaria de la primera mitad del siglo Xx, del formalismo ruso y checo al estructuralismo, pasando por la estilística, la poética morfológica alemana y el New Criticism, se definieron en oposición al historicismo (y el positivismo) del siglo anterior. Es comprensible que nuevas orientaciones críticas consecuentes a la quiebra de ese paradigma, desde la llamada «crisis de la literariedad», en la medida en que pretenden insertar la literatura en coordenadas comunicativas y contextuales más amplias, apunten a una revalorización o una vuelta a la historia literaria desde otros supuestos, en particular los que privilegian el polo de la recepción ${ }^{59}$. Basta recordar el título del famoso discurso de Jauss: «La historia literaria como desafío a la ciencia literaria».

Desde esa nueva actitud, se ha recordado que ya los formalistas rusos dejaron apuntado el camino de regreso a la historia al plantear el problema de la evolución literaria y el de la relación de la literatura con otras series culturales ${ }^{60} \mathrm{y}$ algunos entienden que «solamente ella [la historia] puede ser el lugar de síntesis de aquellas series (como decían los formalistas checos) en las que se inscribe el enigma de la literariedad» ${ }^{61}$. En la reivindicación de la historia con propósitos renovadores confluyen diversas corrientes y metodologías: por ejemplo, la sociología de los hechos literarios, la teoría marxista y neomarxista, la estética de la recepción del grupo de Constanza, la recuperación del pensamiento de Mijail Bajtín, la semiótica y la prag-

59 Véase Joan Oleza y Teresa FERRER, «La teoría literaria y la historia en el siglo XX: tomando posiciones», en A. LÓPEZ GARCÍA y E. RODRÍGuEZ CuADros (eds.), Miscel.lània Homenatge Enrique García Díez, Universitat de Valencia, 1991, pp. 569-582.

${ }^{60}$ Por ejemplo, H. R. JAUSS, La historia de la literatura como provocación [1970], trad. de Juan Godo Costa y José Luis Gil Aristu, Barcelona, Península, 1976, pp. 160161; Claudio Guillén, Teorías de la historia literaria (Ensayos de Teoría), Madrid, Espasa-Calpe, 1989, p. 230; Itamar EvEN-ZOHAR, «Factores y dependencias en la Cultura: Una revisión de la Teoría de los Polisistemas» [1997], trad. de M. Iglesias Santos, en M. Iglesias Santos (comp.), Teoría de los Polisistemas, Madrid, Arco Libros, 1999, pp. 23-52.

61 José-Carlos MAINER, «Historia e historia literaria», en S. SALAÜN y C. SERRANO (eds.), Histoire de la littérature espagnole contemporaine XIXe-XXe siècle: Questions de Méthode, Presses de la Sorbonne Nouvelle, 1992 (pp. 25-34), p. 25. 
mática, las investigaciones sobre fenómenos de intertextualidad o las teorías sistémicas.

Precisamente la teoría de los polisistemas, que irrumpe en la escena internacional a mediados de los setenta de la mano de Itamar Even-Zohar y que ha tenido su mayor impacto quizás en la literatura comparada, se pretende a la vez continuadora de la tradición del formalismo y profundamente interesada por incorporar la dimensión diacrónica e histórica del sistema literario. Su clara voluntad empírica se traduce en la necesidad de confrontar sus hipótesis con situaciones históricas concretas, o de combinar la investigación teórica y la histórico-descriptiva.

También la teoría reciente de acento americano favorece este clima de nuevo interés por la historia, en la medida en que, como señala Culler, tiene, en conjunto, como tarea principal «la crítica de todo lo que se toma por natural, la demostración de que todo lo que se ha tomado o declarado como "natural" es en realidad un producto histórico y cultural» ${ }^{62}$. Los estudios feministas y más recientemente los afroamericanos y poscoloniales se plantean la historia literaria como construcción y cuestiones como la autoridad del texto literario, la relación entre textos canónicos y no canónicos, o entre los géneros de la ficción y los factuales o documentales.

El «nuevo historicismo», influido por la antropología de la cultura (C. Geertz) y los trabajos de Michel Foucault, se propone renovar la historia literaria considerando la literatura como una de las manifestaciones discursivas que conviene volver a situar dentro de los conjuntos culturales más amplios de los que formaba parte en origen. El enfoque antropológico permite remediar una de las debilidades crónicas de la historia literaria: el supuesto de la literatura como algo dado, categoría idéntica a sí misma a través de la historia y no como un artefacto o un concepto normativo. Así los trabajos del nuevo historicismo se ocupan preferentemente de la aparición y la invención de la literatura, así como de la historización de su concepto. Aunque Alan Liu ha considerado, en un muy lúcido ensayo, que el nuevo historicismo «es la última versión del formalismo, el movimiento que enseñó a la crítica a sentirse incómoda ante la historia» ${ }^{63}$ y le ha reprochado carecer de una teoría y un método plenamente históricos, ser incapaz de encontrarse a sí mismo, como el proceso mismo de la historia, al cruzar los periodos, no enclaustrándose en uno de ellos ${ }^{64}$.

Es también evidente la implicación necesaria de hermenéutica e historia, tanto en la determinación del sentido literal —lo que resulta obvio-

${ }^{62}$ J. CULler, op. cit., p. 25.

${ }^{63}$ Alan LIU, «El poder del formalismo: el Nuevo Historicismo» [1989], trad. de Lara Vilà Tomàs, en A. PENEDo y G. PONTÓN (comps.), Nuevo Historicismo, Madrid, Arco Libros, 1998 (pp. 193-261), p. 234.

${ }^{64}$ Ibidem, p. 261. 
como en la del sentido alegórico o espiritual ${ }^{65}$. Precisamente en la permanente interacción entre el análisis textual inmanente y el conocimiento del contexto reside el aspecto tal vez más crucial del así denominado «círculo hermenéutico»: la comprensión de los textos es imposible sin un conocimiento del trasfondo histórico, social y literario, a la vez que este conocimiento está sacado precisamente de los textos mismos; circularidad que se podría condensar en la fórmula de cuño neohistoricista «textualidad de la historia e historicidad de los textos».

Con el mismo recurso al quiasmo se podría definir la doble tarea que debe abordar la teoría para reconciliarse con la historia: «teoría de la historia literaria e historia de la teoría literaria».

En cuanto a la historia de la teoría, debería verse favorecida por la orientación de la teoría reciente a ponerse a sí misma como problema, como objeto de estudio. Así, por ejemplo, Gerald Graff ha llegado a considerar que el único modo de dar salida a los conflictos de la crítica, en cualquier momento, no es buscarles su solución, sino evidenciarlos empíricamente, historiarlos y enseñarlos ${ }^{66}$. Estaremos de acuerdo por lo menos en que es un modo eficaz y legítimo, si no el único. Y será un buen remedio para no caer en las tentaciones apocalípticas que favorece una cierta retórica de la crisis de la teoría. Se podrá comprobar así seguramente, por ejemplo, que el «escenario» de la crisis actual no difiere demasiado del que enfrentó a los historicistas de la tradición filológica con los esteticistas - considerados subversivos, carentes de base y promotores de un peligroso subjetivismo- a principios del siglo XX. Y que la teoría literaria tiende a incurrir, lo mismo que la cultura o la ideología, en una idealización del pasado, en el sueño de una «edad de oro» del consenso perdido, que nunca existió. Un buen ejemplo de cómo se puede hacer teoría literaria al historiarla me parece el libro de Doležel Occidental Poetics, traducido por Luis Alburquerque con el título de Historia breve de la poética ${ }^{67}$.

En la otra vertiente, la de una teoría de la historia literaria ${ }^{68}$, habrá que comenzar por un examen crítico de la situación. Los progresos que se han producido en los últimos decenios conciernen sobre todo a la historia social e institucional. Los aspectos más tradicionales de la historia literaria

\footnotetext{
${ }^{65}$ Como muestra convincentemente Peter SzONDI, Einführung in die literarische Hermeneutik, Frankfurt a. M., Suhrkamp, 1975; trad. por Cristina Naupert de las pp. 926 en J. Domínguez Caparrós (comp.), Hermenéutica, cit., pp. 59-74: «Introducción a la hermenéutica literaria».

${ }^{66}$ Gerald GRAFF, «Other Voices, other Rooms: Organizing and Teaching the Humanities Conflicts», New Literary History, 21, 1990, pp. 817-839. Cf. J. M. PozUELO YvANCOS, «El conflicto de las humanidades y la teoría literaria: una retórica de la crisis», Prosopopeya, 1, 1999, pp. 91-114.

${ }^{67}$ Cit. supra.

68 Véase Luis Beltrán Almería y José Antonio EsCRIG (coords.) Teorías de la historia literaria, Madrid, Arco Libros, 2005.
} 
parecen más estancados y con no pocos problemas sin resolver: su apego a la segmentación cronológica y la periodización, el desaprovechamiento de los instrumentos de análisis cuantitativo disponibles en la actualidad (bibliometría, lexicografía estadística, etc.); el que no haya conseguido nunca dotarse de un objeto específico de estudio; pero sobre todo, la noción acrítica de la literatura como un dato histórico, en vez de como un artefacto cultural basado en un canon restrictivo que ha sido instituido, al menos en parte, por la disciplina que pretende estudiarlo ${ }^{69}$. En Francia el estudio de la historia de las «condiciones sociales de la producción de las obras literarias» (Lanson), de la institución literaria y de la lectura ha pasado, por abandono de la historia literaria, a ser objeto patrimonial de historiadores y sociólogos. Particularmente influyentes son los estudios del «campo» literario moderno, sobre todo de Pierre Bourdieu ${ }^{70}$.

Uno de los aspectos del nuevo interés por la historia que resulta más congruente con el rumbo apuntado ya de la teoría literaria reciente es el que señalan estas palabras de Peter Bürger: «una crítica de la historia literaria tradicional $[\ldots]$ debe poner al descubierto los supuestos de este discurso [...] el discurso de la historia literaria tradicional se caracteriza por la falta de reflexión en torno a su propia historicidad» ${ }^{71}$. Entre nosotros José-Carlos Mainer se ha expresado en el mismo sentido: «La historia de la literatura que recibimos heredada —el canon y su interpretación- debe empezar por ser objeto de historia y, en la medida en que es un producto ideológico, víctima prudente pero certera de deconstrucción» ${ }^{72}$. Y, en esa línea, ha llegado a hablar de la «invención» de la literatura española ${ }^{73}$ por parte del nacionalismo liberal, aunque sin negar la conciencia de una tradición literaria propia, detectable en el Humanismo del siglo XVI o en el XVIII. Es significativo que no contemos con una historia de las historias de la literatura española.

${ }^{69}$ Cf. Philippe Roussin y Jean-Marie SCHAEFFER, «Études littéraires», en O. DUCROT y J.-M. SCHAEFFER, Nouveau dictionnaire encyclopédique des sciences du langage, París, Seuil 1995, s.v., pp. 73-89 (Ed. esp. dirigida por Marta Tordesillas: Madrid, Arrecife, 1998).

${ }^{70}$ Las reglas del arte. Génesis y estructura del campo literario [1992], trad. de Thomas Kauf, Barcelona, Anagrama, 1995.

71 «On Literary History», Poetics, 14, 3/4, 1985 (pp. 199-207), p. 201. Véase la monumental Letteratura italiana dirigida por Alberto Asor Rosa (Turín, Einaudi, 1982, 15 vols.), cuyos primeros volúmenes se titulan, respectivamente, «Il letterato e le istituzioni», «Produzione e consumo», «Le forme del testo», «L'interpretazione», etc., como ejemplo de otra manera de hacer historia literaria.

${ }^{72}$ Historia, literatura, sociedad, Madrid, Instituto de España / Espasa-Calpe, 1988, p. 33 .

${ }_{73}$ «La invención de la literatura española», en J. M. ENGUITA y J.-C. MAINER (eds.), Literaturas regionales en España, Zaragoza, Institución «Fernando el Católico», 1994 (pp. 23-45), pp. 23-25. 
Una dificultad fundamental tiene que ver con la naturaleza problemática de la relación entre la historia literaria y la historia, sobre todo por la quiebra de la filosofía de la historia de herencia hegeliana (la historia como proceso objetivo y continuo) bajo cuyo influjo se había constituido: la historia literaria no está ya en condiciones de decir de qué totalidad histórica o de qué historia colectiva singular forma parte. Gumbrecht ha llegado a proponer separar la perspectiva histórica y la apreciación estética confundidas en la historia literaria tradicional y dar paso a una historia «pragmática» de la literatura, basada en la hipótesis de que los textos literarios son la objetivación de situaciones de comunicación específicas y un objeto privilegiado para la reconstrucción de la historia de las mentalidades ${ }^{74}$. Aunque convendría recordar también que algunas aportaciones de la historia literaria más tradicional o filológica no sólo muestran una solidez incuestionable, sino que resultan literalmente irrenunciables para los estudios literarios. Pienso sobre todo en la crítica textual que, extendiendo a la literatura moderna las técnicas de la filología clásica alemana, permite fijar los textos: nada menos que nuestro objeto de estudio.

Es cierto que la crítica textual se ha aplicado a la fijación de un canon de obras consagradas y que la historia literaria tradicional ha estado fundamentalmente orientada a la justificación de ese canon. De ahí que una de las tareas básicas de una teoría de la historia literaria sea precisamente el estudio de la formación del canon. Por otra parte, es la perspectiva diacrónica o histórica la adecuada para un objeto como el canon literario, «esencialmente dinámico», que «es, a la postre, el diálogo entre el presente y el pasado, entre la originalidad y la influencia, entre la aspiración indefinida y los resultados inevitables», «una lectura intencional» o «una permanente actualización del pasado» ${ }^{75}$. Por eso creo que existe contradicción en pretender abrirlo, al menos hasta cierto punto, aunque parezca a primera vista la solución más «liberal», pues el canon «existe precisamente con el fin de imponer límites, de establecer un patrón de medida» ${ }^{76}$. Claro que esto es así tan sólo desde el punto de vista sincrónico, que es, lógicamente, el propio del debate y, más directamente, de la lucha por defenderlo o transformarlo; mientras que, visto diacrónicamente, el canon está siempre, en cierto modo, abierto.

El acalorado debate en torno al canon se sitúa no sólo en esa dimensión sincrónica, sino también en la valorativa, normativa o prescriptiva que nos aleja del estudio y nos empuja a la acción, a la lucha directa por de-

\footnotetext{
${ }^{74}$ Cf. Ph. Roussin y J.-M. SCHAEFFER, art. cit.

75 J.-C. MAINER, «Sobre el canon de la literatura española del siglo XX», en E. SULLÀ (comp.), El canon literario, cit. (pp. 271-299), pp. 299, 274 у 272.

${ }^{76}$ Harold BLOOM, El canon occidental [1994], trad. de Damián Alou, Barcelona, Anagrama, 1995; cito por la reproducción del capítulo «Elegía al canon», en E. SULLÀ (comp.), El canon literario, cit. (pp. 189-219), p. 212.
} 
fenderlo, transformarlo o abolirlo. A pesar de lo cual cabe alguna reflexión al respecto, sin rehusar el compromiso. Un dato sintomático de la correlación de fuerzas me parece, que en el volumen compilado por Enric Sullà sobre el asunto ${ }^{77}$, un solo texto, el de Harold Bloom, defienda la canonicidad frente a los otros nueve, que la cuestionan. Sin embargo, creo que los «críticos», por muchas batallas como ésta que ganen en el terreno de las ideas o de las opiniones, perderán la guerra de los textos si dejan a Homero, a Dante, a Cervantes, a Shakespeare como señas de identidad de los «conservadores».

Hay componentes de la llamada por Bloom «escuela del resentimiento» que se resisten, en cambio, a dejar los textos canónicos a la parte contraria en exclusiva. Así, por ejemplo, el nuevo historicismo, centrado nada menos que en Shakespeare y el Renacimiento inglés, de una parte, y el Romanticismo, de otra. Edward Said ha señalado la fuerza crítica de los clásicos, su carácter frecuentemente contradictorio, su compromiso tanto con la conquista colonial como con la liberación ${ }^{78}$. Y Jonathan Culler sostiene que los textos canónicos son muchas veces los más poderosos desmitificadores de las ideologías que se ha dicho que sustentan ${ }^{79}$. Y es que la noción misma de texto «clasico» o canónico presenta una profunda ambigüedad o contradicción: pueden entenderse como textos que dicen siempre lo mismo a un hombre siempre idéntico, pero también que dicen cosas distintas a distintos hombres; que pueden, pues, exaltar la diferencia tanto como la identidad.

Claro que no basta con admitir el «uso» de obras canónicas. Depende de cómo se haga, y, en definitiva, de que se acepte o se niegue su «canonicidad». Así, por ejemplo, los «estudios culturales», una vez incorporado el posmodernismo al final de los años ochenta, no vetarían seguramente una lectura de poemas de Góngora; pero siempre y cuando se la considere equivalente a -es decir, intercambiable por- otra de los ripios de cualquier famosillo televisivo con veleidades seudopoéticas. Y, francamente, la tolerancia no puede abusar tanto del sentido común. Estoy con Steiner:

Considerar que Sófocles, Dante o Shakespeare están mancillados por una mentalidad imperialista, colonialista, es pura y simple estupidez. Desechar la poesía o la novela occidentales desde Cervantes hasta Proust por «machismo» es ceguera. [...] Que Bach y Beethoven llegan a límites del empeño humano que sobrepasan el rap o el heavy metal; que Keats pone en solfa ideas a las que Bob Dylan es ajeno, es o debiera ser algo evidente por sí mismo, sean cuales fueren las connotaciones político-sociales $-\mathrm{y}$ en efecto las hay- de tal convicción.

\footnotetext{
${ }^{77}$ Cit. en las dos notas anteriores.

${ }^{78}$ Edward SAID, Cultura e imperialismo [1993], trad. de Nora Catelli, Barcelona, Anagrama, 1996, p. 493.

79 Op. cit., p. 154.
} 
[...] Las ciencias no conocen semejante estupidez. Este punto crucial se pasa a menudo por alto. El legado de Arquímedes, Galileo, Newton y Darwin sigue estando seguro. [...] En la ciencia, la engañifa, y mucho más la falsificación por motivos de raza, género o ideología está - hasta donde es humanamente posible- excluida. La corrección es la de la ecuación, no la de la política de la cobardía. Esta diferencia — podemos conjeturar- ayuda a explicar el relativo prestigio y dignidad que actualmente poseen las ciencias y las letras humanas ${ }^{80}$.

Si buscamos vías de futuro serias y responsables para resolver la crisis de identidad de la historia literaria y para construir un modelo teórico resistente en que sustentarla, proyecto tan difícil como necesario, habrá que apelar indiscutiblemente a la literatura comparada, principal estímulo para superar la estrechez de los horizontes nacionales (y no digamos de los nacionalismos asfixiantes); aunque creo que no antagónica, sino complementaria con el interés actual por literaturas regionales o locales, incluso «particulares» en un sentido no geográfico, sino social o cultural (como la literatura femenina, de minorías raciales, culturales o de orientación sexual, etc.): «Ninguna disciplina más oportuna y mejor adecuada al espíritu de una época [antinacionalista] deseosa de superar la ambición fragmentaria y la investigación sin salida». Son palabras de Claudio Guillén que parecen referidas a la situación actual, pero que datan en realidad de $1957^{81}$. Me refiero, claro está, a la literatura comparada en el sentido o en la dirección de la literatura general (o universal), tal como la definía, por ejemplo, ya en 1958, Albert Guérard: «El estudio de los problemas comunes a todas las literaturas: temas, formas, géneros, caracteres (o personajes), fuentes de inspiración, relaciones con todas las formas de la cultura y de la civilización» ${ }^{82}$; programa que valdría prácticamente lo mismo para definir el objeto de la teoría.

Es este campo de la conjunción entre teoría e historia el que presenta la mayor dificultad y al que venimos apuntando como solución al conflicto secular entre las dos disciplinas. Un buen ejemplo de que se puede hacer teoría de la historia es, a mi juicio, el libro de Peter Szondi, de 1956, Teoría del drama moderno (1880-1950) ${ }^{83}$, en el que se estudia brillantemente la evolución de las formas de un género en un periodo de tiempo determinado. Se trata, en fin, como digo, también de un camino especialmente prometedor para renovar la historia literaria, librándola del reproche que dirige Bajtín a sus artífices: «No perciben, más allá de la mezcla de colores y del alboroto superficial del proceso literario, los grandes y esenciales des-

${ }^{80}$ G. STEINER, Lecciones de los Maestros [2003], trad. de María Condor, Madrid, Siruela, 2004, pp. 137-138.

81 «Literatura como sistema», en Filologia romanza.

${ }_{82}$ Apud G. de Torre, op. cit., p. 183.

83 Trad. de Javier Orduña, Barcelona, Destino, 1994. 
tinos de la literatura y de la lengua, cuyos principales personajes son, en primer lugar, los géneros, mientras que las corrientes y las escuelas son tan sólo héroes de segundo y tercer orden» ${ }^{84}$.

\section{DimENSIÓN DisCURSIVA: RetóRICA y PoÉtiCA}

Seguramente ninguna otra disciplina suscita, en el archipiélago de corrientes post-estructuralistas, tanta fascinación como la retórica, que ejerce un verdadero imperio sobre la teoría literaria de las últimas décadas, tanto la más disciplinada como la más subversiva. Basta pensar en la función central que se concede a la retórica en los análisis textuales de los deconstruccionistas de la escuela de Yale, en particular de Paul de Man. Stanley Fish ha propuesto cambiar la denominación de los departamentos de inglés por departamentos de retórica, según Aguiar e Silva, y, todavía más radicalmente, Terry Eagleton apunta a la sustitución por la retórica de unos estudios literarios ampliados a estudios culturales o teoría de los discursos ${ }^{85}$.

La retórica o teoría del discurso comparte con el formalismo, el estructuralismo y la semiótica el interés por los recursos formales del lenguaje, pero al igual que la teoría de la recepción, también se interesa en ver cómo funcionan eficazmente esos recursos donde se les «consume». Su preocupación por el discurso como forma de poder y de deseo puede aprender mucho de la teoría de la deconstrucción y en la teoría psicoanalítica; y su creencia en que el discurso puede transformar al hombre tiene muchos puntos de contacto con el humanismo liberal ${ }^{86}$.

Pero conviene distinguir por lo menos dos aspectos u orientaciones de la retórica actual que, si bien están relacionados, son no sólo distintos sino en buena medida contradictorios. Por lo menos se trata de dos caminos divergentes.

El primero, de índole cultural, tiene que ver con el carácter retórico de la cultura posmoderna, que favorece, una vez que se considera imposible la adecuación entre lenguaje y realidad, la vuelta a una retórica desprovista de cualquier relación con la verdad, convertida en sofística, presidiendo una cadena sin fin de textos que remiten a otros textos... y así ad infinitum; la que define el tipo humano que ha denominado «homo rhetoricus» $\mathrm{M}$. A. Garrido Gallardo ${ }^{87}$ y se traduce en prácticas de dominio, mediante la ma-

${ }^{84}$ Mijail BAJTín, Teoría y estética de la novela: Trabajos de investigación [1975], trad. de Helena S. Kriúkova y Vicente Cazcarra, Madrid, Taurus, 1989, p. 453.

${ }_{85}$ Terry Eagleton, Una introducción a la teoría literaria [1983], trad. de José Esteban Calderón, Madrid, FCE, 1993, pp. 243-245.

${ }^{86}$ Ibidem, p. 244.

87 «Homo rhetoricus», en Investigaciones semióticas III: Retórica y lenguajes, Madrid, UNED, 1990, vol. I, pp. 23-38; también «Humanismo y retórica», Prosopopeya, 1, 1999, pp. 49-69. 
nipulación de los discursos, o bien de crítica, al desvelar las trampas, los mecanismos de esas manipulaciones.

No extraña la fascinación que ejerce este tipo de retórica en las corrientes post-estructuralistas más antidisciplinares y relativistas. Primero, porque representa la negación del proyecto de construir una «ciencia de la literatura», aspecto que explica la posición antirretórica de la tradición filosófica y científica europea que va de Platón a Kant y a Habermas. También, y de forma decisiva, porque se trata de un saber con vocación política, de un instrumento de poder y de hegemonía, que, según el tópico neomarxista, habrá que devolver a las víctimas y los marginados del poder.

Este aspecto es particularmente importante en los «estudios culturales» que, con un objeto de estudio difuso (cine, publicidad, ideología, arte, literatura, etc.) y sin haber constituido ni poder constituir un método que configure su disciplinariedad, encuentran precisamente en esta dirección los únicos principios de orientación comunes: un neomarxismo doctrinalmente light y una agenda política contra la derecha (de Thatcher y de Reagan). Contaba el profesor Aguiar e Silva el caso de una especialista británica en literatura renacentista que afirmaba en una reunión de este tipo de estudios: «Mi método consiste en enseñar a Shakespeare de tal modo que contribuya a la caída de la Sra. Thatcher». Es difícil dejar de señalar dos perplejidades: ¿Cómo puede el neomarxismo, por light que sea, compaginarse con «el fin de las grandes narrativas» que propugna el posmodernismo, ya integrado a los estudios culturales? ¿Y cómo se puede practicar un relativismo radical, en literatura, en arte, y estar a la vez al servicio de un proyecto político que no se relativiza nunca?

La otra cara del éxito de la retórica en la actualidad es de tipo académico o disciplinar. El giro que experimenta la teoría post-estructuralista del lenguaje (también del literario) abriéndose a la dimensión pragmática del hecho comunicativo - al discurso o el texto, en vez de la frase, como unidad significativa; al estudio de la producción de significado como un proceso en que están implicados emisores, receptores y circunstancias- no puede ser más convergente con la retórica como ciencia del «discurso».

Como hitos que han allanado el camino de esta vuelta de la retórica como disciplina, habría que recordar por lo menos los trabajos renovadores del Grupo $\mu$ de la Universidad de Lieja en los años setenta ${ }^{88}$, así como la síntesis del corpus clásico que realizó Lausberg en $1960^{89}$ y, antes, el Tratado de la argumentación, de Perelman y Olbrechts-Tyteca ${ }^{90}$, en la direc-

${ }^{88}$ Retórica general [1970], trad. de J. Victorio, Barcelona, Paidós, 1987; Rhétorique de la poésie, París, PUF, 1977.

${ }^{89}$ Heinrich Lausberg, Manual de Retórica literaria [1960], trad. de José Pérez Riesco, Madrid, Gredos, 1966-1969, 3 vols.

${ }^{90}$ Chaïm PeRElman y Lucie OlBREChTS-TYTECA, Tratado de la argumentación: La nueva retórica [1958], trad. de Julia Sevilla Muñoz, Madrid, Gredos, 1989. 
ción más general, no sólo literaria, que ha tenido un desarrollo espectacular hasta nuestros días en ámbitos como la publicidad y la propaganda, la política, el marketing empresarial, etc.

Si hubiera que señalar algunos síntomas del interés actual por la retórica académica, sin mencionar los proyectos de investigación que viene desarrollando en el CSIC el Equipo de «Teoría del lenguaje literario» (ahora de «Análisis del Discurso») durante los últimos años ${ }^{91}$, bastaría recordar, limitándonos a la década de los noventa y a España, las Actas de Congresos como las editadas por Hernández Guerrero ${ }^{92}$ o por Albaladejo y otros ${ }^{93}$; o la cuarta edición del ya clásico libro de Spang ${ }^{94}$, el Manual de Azaustre y Casas ${ }^{95}$, las Figuras de Mayoral ${ }^{96}$ o incluso las mías ${ }^{97}$. En esta orientación, más seria y responsable a mi juicio pero que otros tildarán de más tradicional, la neorretórica viene a confluir con disciplinas como la semiótica, la pragmática, las teorías del texto; incluso con la vertiente textual de la estética de la recepción, de la hermenéutica y de la deconstrucción, como ya he dicho.

Pero si en el sentido señalado antes, la retórica supone la negación de la poética como saber, en este otro no sólo se encuentran las dos en un espacio común, el del discurso o el texto en su más amplia extensión, sino que tienden a confundirse como ponen de manifiesto expresiones del tipo «retórica de la ficción» y «poética lingüística». Esta conjunción de poética y retórica, rodeadas de las disciplinas que acabo de nombrar, representa en mi opinión la línea en que la teoría post-estructuralista es continuadora y heredera genuina del paradigma anterior.

La clave teórica de la supervivencia de ese paradigma, o de sus posibilidades de prolongación, radica seguramente en algo que la poética ha tardado en comprender: que no había que confundir la tesis (discutible) de la autoteleología de la obra literaria con el principio metodológico de la autonomía de su estudio en cuanto manifestación de arte verbal. En la

${ }^{91}$ Véase el CD-Rom Retóricas españolas del siglo XVI escritas en latín, M. A. GARRIDO GALLARDO (ed.), revisión filológica de A. L. Luján Atienza, CSIC-Fundación Ignacio Larramendi, 2004.

92 José Antonio Hernández Guerrero (ed.) Poética y Retórica, Cádiz, Universidad, 1991; Retórica, Texto y Comunicación, Cádiz, Universidad, 1994.

${ }_{93}$ Tomás Albaladejo y otros (eds.) Quintiliano. Historia y actualidad de la retórica, Logroño, Instituto de Estudios Riojanos, 1998, 3 vols.

${ }^{94}$ Kurt SPANG, Fundamentos de retórica literaria y publicitaria [1979], Pamplona, Eunsa, 4a ed., 1997 (ha aparecido después todavía una versión renovada con el título Persuasión: Fundamentos de retórica, Pamplona, Eunsa, 2005.)

${ }_{95}$ Antonio Azaustre y Juan CASAS, Manual de Retórica española, Barcelona, Ariel, 1997.

96 José Antonio MAYORAL, Figuras retóricas, Madrid, Síntesis, 1995.

97 J.-L. GARCía BARRIENTOS, Las figuras retóricas: El lenguaje literario 2 [1998], Madrid, Arco/Libros, $2^{\mathrm{a}}$ ed., 2000. 
práctica, el fundamento de su supervivencia está sencillamente en la importancia y solidez de sus aportaciones, que ya he ponderado antes y que se ponen de manifiesto cuando hay que afrontar los «problemas» literarios, que siguen tozudamente ahí, después de todas las divagaciones metateóricas ${ }^{98}$.

Por otro lado, el pedigrí de una poética actual no puede ser ni más selecto ni más fértil: desde la Poética de Aristóteles en el origen, pasando por toda la tradición clasicista y en gran medida también por la teoría romántica, hasta la brillante y fecunda eclosión que conoce durante el siglo XX en corrientes o etapas como el formalismo ruso, el círculo de Bajtín, el círculo lingüístico de Praga, la escuela morfológica alemana, la fenomenología literaria, el New Criticism, los neo-aristotélicos de Chicago, el estructuralismo francés, en su doble vertiente, semiótica y propiamente literaria, la escuela de Tartu y, en mayor o menor medida, la semiótica italiana, la ciencia empírica de la literatura, la sociocrítica o la teoría de los polisistemas, así como de autores «no alineados» de la talla de E. Auerbach, N. Fry, etc. Impresionante estirpe, a la que no parece fácil encontrar parangón.

A la vista de semejante genealogía, es natural que en la crisis del estructuralismo a finales de los años setenta, con el desplazamiento de acento hacia las diversas hermenéuticas post-estructuralistas y hacia la historia social de la literatura, la poética sufriera una pérdida de visibilidad o pasara a un segundo término. Pero ello le ha permitido definir mejor su idiosincrasia y su posición en el conjunto, más o menos concertado, de las disciplinas literarias, de forma que sale reforzada y depurada de la citada crisis y se presenta en la actualidad tan fecunda como lo ha sido, para no remontarnos más atrás, desde comienzos del siglo XX.

La poética actual puede definirse, fiel al concepto aristotélico, como el estudio del arte literario en cuanto creación verbal. Parece claro hoy que carecen de fundamento las objeciones que se le han hecho tanto en nombre de la inefable individualidad de cada obra literaria como en nombre de la complejidad histórica y social de los hechos literarios; tampoco la de que no podrá ser puramente descriptiva al ser la literatura un dominio de valores, pues ella estudia el arte literario, no en cuanto valor estético, sino como técnica, como conjunto de procedimientos. Perfectamente compatible con el pluralismo metodológico, complementaria y no competidora de otros enfoques (histórico, filosófico, sociológico, psicológico, etc.), la poética aísla un objeto de estudio específico en el campo de la literatura: el «arte» literario y quizás más ampliamente la creación verbal, lo que la vincula con las ciencias del lenguaje y en particular con la retórica. Dos fenómenos se cruzan, pues, en su empeño: discursivos y artísticos. En relación con cada uno

\footnotetext{
98 Así por ejemplo, cuando Ángel Luis LujÁn ATIENZA debe explicar Cómo se comenta un poema (Madrid, Síntesis, 1999), de forma práctica, tiene que reconocer que los recursos fundamentales son los que proporciona - todavía-la estilística (pp. 13-14).
} 
debe definir la poética lo específico de la literatura: en relación con otras prácticas discursivas y en relación con otras prácticas estéticas.

En cuanto a lo primero, la poética se empeñó por mucho tiempo en la búsqueda, fracasada pero no estéril, de una combinación de rasgos sintácticos y semánticos que permitieran aislar una lengua literaria o poética. Al desplazar el objetivo hacia una función poética del lenguaje, Jakobson plantea la cuestión en el plano discursivo, lo que supone un avance indudable, pero insuficiente. Pues si da cuenta de la dicción literaria (de la poesía definida formalmente), no lo hace de la ficción, el otro componente de lo que llama Genette literariedad constitutiva. Y a ésta hay que añadir aún la condicional, que resulta, no de una intencionalidad, sino más bien de una «atención» estética, que depende en último término del receptor ${ }^{99}$. Tanto este régimen condicional como la ficción implican una definición pragmática de la literatura y la cuestión de su institucionalización se hace así pertinente para la poética. En cuanto al estatuto semiótico del arte verbal en relación con las demás artes, la literatura se encuentra atravesada por la distinción, establecida por Goodman ${ }^{100}$, entre artes alográficas (con notación sintáctica: la música) y artes autográficas (sin esquema de notación: la pintura), diferencia, de estatuto semiótico y pragmático, entre la literatura oral y la escrita, que resulta capital en lo que se refiere al teatro.

Por otra parte, la poética no aparece hoy separada, sino al contrario estrechamente relacionada con las otras dos grandes líneas que he destacado en los epígrafes anteriores. Algunos de sus desarrollos actuales plantean la cuestión de la intencionalidad en planos concretos. Así, por ejemplo, de una parte, el creciente interés por las obras de realización oral; de otra, el estudio de los «avant-textes» y, más en general, el desarrollo de la genética textual o la crítica genética, que, además de como auxiliar del trabajo filológico (ediciones críticas), aborda también, en un plano más teórico, el estudio de la genésis textual en sí misma, sin descartar el hallazgo de eventuales constantes antropológicas en la misma. Por lo que se refiere a la historia, si es cierto, como he dicho antes, que el paradigma formalestructuralista reacciona contra el historicismo, lo que hace que en muchos casos se subestime la importancia de la dimensión histórica, no lo es en absoluto que sea inherente a la poética el volver la espalda a la historia. Basta pensar en los formalistas rusos y su interés por la periodización y sobre todo por la evolución literaria, o en las tempranas llamadas a una renovación de la historia literaria por parte de Barthes ${ }^{101}$. Los estudios de

${ }^{99}$ G. GenetTe, Ficción y dicción [1991], trad. de Carlos Manzano, Barcelona, Lumen, 1993, pp. 11-34.

100 Nelson Goodman, Los lenguajes del arte [1968], trad. de Jem Cabanes, Barcelona, Seix Barral, 1976. Distinción desarrollada luego por G. GenETTE, La obra de arte: inmanencia y trascendencia [1994], trad. de Carlos Manzano, Barcelona, Lumen, 1997.

101 Véase Roland BARTHES, «Histoire ou littérature?» [1960], en Sur Racine, París, Seuil, 1963, pp. 145-167. 
Genette —quien ya señaló en 1969 la necesidad de que el análisis formal se abra en un cierto punto a la diacronía ${ }^{102}$ - sobre la hipertextualidad o el paratexto son estructurales e históricos al mismo tiempo ${ }^{103}$, como podría calificarse de poética histórica el libro de Szondi, Teoría del drama moderno, al que me referí antes. Y que viene al caso para destacar que la problemática de los géneros literarios pone de manifiesto de manera privilegiada el carácter indisociable de las dimensiones estructural e histórica. Se trata de categorías transhistóricas, no suprahistóricas. En definitiva, las distinciones analíticas de la poética no se oponen a la consideración de la variabilidad diacrónica de la literatura; al contrario, permiten calibrarla en toda su amplitud y plantearla de forma rigurosa ${ }^{104}$.

Pero seguramente la mejor prueba de la vitalidad en el panorama postestructuralista de la poética, y del paradigma anterior en general, es la vigencia de la que seguramente es su manifestación más depurada: la narratología, tal como la propuso Todorov ${ }^{105}$ y como la ha construido magistralmente Genette en su «Discurso del relato» ${ }^{106}$ (otra expresión, por cierto, reveladora de la conjunción entre retórica y poética). La narratología puede ilustrar también mi convencimiento de que esta línea de convergencia entre retórica y poética no sólo ha proporcionado los mejores frutos en la teoría literaria del siglo Xx, sino que se presenta cargada de futuro hoy, cuando empieza a vislumbrarse la superación del panorama fragmentario, inestable y confuso de los diversos post-estructuralismos.

Este convencimiento lo he predicado, claro, con el ejemplo, de la forma más comprometida, a través de mi propia actividad teórica, que se ha movido y se mueve en esta línea, en una dirección que apunta a los orígenes y pone de manifiesto una cierta paradoja, la de que la poética, a pesar de su raíz aristotélica, haya culminado en una narratología y haya dejado en buena medida de lado la construcción de una dramatología, tarea que es precisamente la que me empeño en llevar a cabo.

Por otra parte, resulta claro que el esbozo de tendencias y enfoques que acabo de hacer no es más que un punto de vista sobre el estado de la cuestión, y quizás el más periférico. Más significativa y penetrante sería una visión de cada una de las cuestiones que integran el temario de la teoría.

102 G. Genette, «Poétique et histoire» [1969], en Figures III, París, Seuil, 1972, pp. 13-20 (trad. de Carlos Manzano: Barcelona, Lumen, 1989).

${ }^{103}$ G. Genette, Palimpsestos: La literatura en segundo grado [1982], trad. de Celia Fernández Prieto, Madrid, Taurus, 1989, y Seuils, París, Seuil, 1987, respectivamente.

${ }^{104}$ Cf. J.-M. SchaefFer, «Poétique», en O. Ducrot y J.-M. SchaefFER, Nouveau dictionnaire..., cit., s.v., pp. 162-178.

105 Tzvetan Todorov, Gramática del Decamerón [1969], trad. de María Dolores Echeverría, Madrid, Taller de Ediciones Josefina Betancor, 1973.

${ }^{106}$ G. GenetTE, «Discours du récit. Essai de méthode», en Figures III, cit., pp. 65282; Nouveau discours du récit, París, Seuil, 1983 (trad. de Marisa Rodríguez Tapia: Madrid, Cátedra, 1998). 
Una síntesis así presentaría aún más dificultades y seguramente también más diferencias. Pero a estas alturas de la exposición no cabe ni siquiera plantearla. Acaso quepa y no resulte inútil ensayar, a título de ejemplo de la vigencia de la poética, una idea sumarísima de la orientación recién mencionada y a la que he pretendido contribuir.

\section{Por ejemplo: La dRAMatología como poÉtica (y RetóRICA) DEL «DISCURSO» TEATRAL}

Se trata de un ejemplo, sí, pero no de cualquiera. Pues sabido es que en la larga y fecundísima tradición clasicista, y a partir sobre todo de la Poética de Aristóteles, el teatro se considera el género literario por excelencia, la manifestación más alta, exigente y perfecta de la «poesía». Por ello el pensamiento literario ha sido, a lo largo de esa tradición, primordialmente una investigación de la teoría (y de la práctica) dramática. No sólo las poéticas clásicas, renacentistas o neoclásicas, de la de Aristóteles a la de Martínez de la Rosa ${ }^{107}$ en España, centran en el teatro su doctrina, sino que las revoluciones más o menos anticlasicistas, como la de Lope de Vega o la de los románticos alemanes o franceses, o el Discurso de Durán ${ }^{108}$, se plantean sobre todo también en el ámbito del drama. Hasta el siglo XIX la polémica literaria por antonomasia es la polémica sobre el teatro.

El cambio de valores que se produce a partir del Romanticismo conducirá en la práctica a la pérdida de la hegemonía del teatro como género literario en beneficio de la lírica y de la novela. Las consecuencias teóricas de esta alteración en el canon genérico se pueden percibir con claridad en el pensamiento literario del siglo $\mathrm{XX}$, en el que se asiste, sin embargo, a una recuperación de la tradición poética y retórica del clasicismo: tanto la estilística como el New Criticism privilegian el poema como objeto de estudio; el formalismo ruso contribuye de forma decisiva a la teoría de la lírica y de la narrativa ${ }^{109}$, lo mismo que el estructuralismo francés, en el que se prolonga; ninguna de estas importantísimas escuelas de pensamiento literario parece interesarse particularmente por el teatro. Es en el amplio, y muchas veces confuso, ámbito de la semiótica donde se producirá el resur-

107 Francisco Martínez DE LA RoSA, Poética española [1827], París, Imprenta de Julio Didot, 1834.

108 Agustín DURÁn, Discurso sobre el influjo que ha tenido la crítica moderna en la decadencia del teatro antiguo español [1828], ed. D. Shaw, Exeter, University of Exeter, 1973.

109 Véase un meritorio empeño por sacar partido teatral al formalismo ruso, en particular a Tomachevski, y sobre todo a su continuación en Maria Serguieievna KURGUINIAN (Tioria Litieraturi, Rodi y Yandri, Moscú, Nauka, 1964, pp. 238-362), en Armando PARTIDA TAYZAN, Modelos de acción dramática: Aristotélicos y no aristotélicos, México, UNAM-Editorial Itaca, 2004. 
gimiento del interés por el teatro en el pensamiento artístico y literario del siglo XX. Los pioneros de la teoría dramática contemporánea (Zich, Mukarovský, Bogatyrev, Honzl, Veltruský) se encuentran en la escuela de Praga, entre 1926 y 1948, aunque su difusión en Europa occidental se retrasa hasta los años 60. Al final de esta década comienza el desarrollo de la moderna semiótica teatral, que adquiere un ritmo vertiginoso en las décadas siguientes.

El casi inevitable umbral de entrada a la teoría teatral es el de la oposición entre literatura y espectáculo o el enfrentamiento entre textocentrismo y escenocentrismo. Desde la discusión protagonizada por Otakar Zich ${ }^{110}$ y Jirí Veltruský ${ }^{111}$, que ha analizado luego Miroslav Procházka ${ }^{112}$, el debate se viene repitiendo, un poco a lo bolero de Ravel, hasta resultar algo cansino. Yo mismo he participado en él, primero apasionadamente en pro del escenocentrismo ${ }^{113}$; luego, sin cambiar en lo sustancial mi posición, con actitud más templada y distante ${ }^{114}$. Cabe, me parece, una solución integradora capaz de admitir la finalidad escénica — que deja su impronta en la estructura- de este tipo de textos y, a la vez, su autonomía (relativa) como literatura, esto es, el acceso por la lectura al universo representado. La distinción conceptual que establezco entre «texto dramático» y «obra dramática» ${ }^{115}$, de la que hablaré luego, pretende precisamente encauzar este conflicto.

En su excelente síntesis, Jean-Marie Schaeffer ${ }^{116}$ distingue cuatro enfoques en la teoría teatral: el antropológico, el semiótico, el lingüístico y el poético. Resulta evidente que tanto el semiótico como el lingüístico —en rigor, parte del anterior - son perfectamente integrables, si no queremos decir que forman parte, de la poética tal como la caracterizamos antes (amalgamada con la retórica); poética que es capaz de asimilar también el enfoque antropológico, una vez superado el planteamiento más o menos evolucionista del origen ritual del teatro, cuando lo pertinente parece investigar lo que tiene en común y lo que diferencia al teatro de otros «géneros

110 Estetika dramatického umení [Estética del arte dramático], Praga, Melantrich, 1931.

111 El drama como literatura [1942], trad. de Milena Grass, Buenos Aires, Galerna/ IITCTL, 1990

112 «Sobre la naturaleza del texto dramático» [1984], trad. de E. Álvarez López, en M. C. Bobes Naves (comp.), Teoría del teatro, cit., pp. 57-81.

113 J.-L. GARcía BARrientos, «Escritura/Actuación: Para una teoría del teatro», Segismundo, 33-34, 1981, pp. 9-50; ahora también en M. C. BoBES NAVES (comp.), Teoría del teatro, cit., pp. 253-294, y en mi libro Teatro y ficción: Ensayos de teoría, Madrid, Fundamentos, 2004, pp. 19-49.

114 Por ejemplo en Cómo se comenta..., cit.

115 J.-L. García BARrientos, Drama y tiempo: Dramatología I, Madrid, CSIC, 1991, pp. 36-42.

116 «Énonciation théâtrale», en O. DUCROT y J.-M- SCHAEFFER, Nouveau dictionnaire..., cit., s.v., pp. 612-621. 
performativos», como juegos, deportes, fiestas, etcétera, de los que el rito mismo forma parte. De hecho, ahí se encuentra el origen y el fundamento de mi teoría, con la dicotomía entre los conceptos de «escritura» y «actuación» y la definición del teatro por su «situación comunicativa», que exige la presencia y el presente de actores y público, y por la «convención representativa», con el desdoblamiento, por simulación del actor y por denegación del público, de todos sus elementos básicos ${ }^{117}$.

La orientación poética en sentido estricto, o sea en el sentido aristotélico, se centra en el análisis de la estructura mimética o representativa, que es común al texto y a la representación. Puede abordarse desde una teoría, bien temática, en el sentido de Vladimir Propp ${ }^{118}$, bien «modal», a la que cabe denominar con propiedad dramatología. La primera conduce, después de pasar por Étienne Souriau ${ }^{119}$, al modelo actancial de Greimas ${ }^{120}$, tan presuntamente universal que se aplica indistintamente a una obra narrativa o teatral o cinematográfica, etcétera; lo mismo que el modelo de análisis de la intriga como un conjunto de movimientos actanciales (moves) propuesto por Thomas G. Pavel ${ }^{121}$. Lo contrario ocurre con la dramatología, que estudia la estructura mimética determinada por el modo de imitación y se sitúa por tanto en el plano en que el drama se opone a la narración y en el que es posible aprovechar, pero críticamente, más pendientes de las diferencias que de las similitudes, el riquísimo arsenal conceptual de la narratología; claro está que de una narratología de carácter no temático sino modal, como lo es expresa y modélicamente la de Gérard Genette.

Éste es precisamente el enfoque desde el que me propongo elaborar una completa teoría del modo dramático de representar mundos imaginarios o ficticios ${ }^{122}$. Intentaré resumir a continuación sus principios fundamentales, aunque de forma necesariamente sumarísima, intentando poner de manifiesto su coherencia interna.

Con base en el concepto aristotélico de modo de imitación, que considero vigente, defino la dramatología como la teoría del modo teatral de representar ficciones. Este modo, que es el de la actuación o el drama, se opone al otro (único) modo, que es el de la narración y, a mi entender,

117 Cf. mi libro Drama y tiempo, cit., pp. 49-75.

118 Morfología del cuento [1928], trad. de María Lourdes Ortiz, Madrid, Fundamentos, 1971 .

119 Les deux cent mille situations dramatiques, París, Flammarion, 1950.

120 Julien-Algirdas GreIMAS, Semantique structurale: Recherche de méthode, París, Larousse, 1966 (versión de Alfredo de la Fuente: Madrid, Gredos, 1971); Du sens: Essais sémiotiques, París, Seuil, 1970 (trad. de Salvador García Bardón y Federico Prades Sierra: Madrid, Fragua, 1973).

${ }^{121}$ La sintaxe narrative des tragédies de Corneille, París-Montreal, Klincksieck, 1976; The Poetics of Plot: The Case of English Renaissance Drama, Minneapolis, University of Minnesota Press, 1985.

${ }^{122}$ Cf. mis libros, citados, Drama y tiempo, Como se comenta... y Teatro y ficción. 
incluye hoy al cine. El rasgo distintivo es el carácter mediado (o no) de la representación. El narrativo es el modo «mediato», con la voz del narrador o el ojo de la cámara como instancias mediadoras constituyentes. El dramático es el modo «in-mediato», sin mediación: el mundo ficticio se presenta -en presencia y en presente- ante los ojos del espectador ${ }^{123}$.

La dramaturgia, término tan de moda que ha llegado a significarlo todo y por tanto a no significar nada, puede definirse con precisión como la práctica del modo teatral de representar argumentos; definición capaz de dar cuenta de la tarea del dramaturgo real en la doble acepción de Dramatiker o escritor de obras, que trabaja más o menos para la literatura, y de Dramaturg o adaptador, consejero, analista, etcétera, que trabaja para un montaje, o sea, para el teatro.

La «situación» comunicativa y la «convención» representativa que le son propias permiten definir el teatro como espectáculo. De la situación teatral resultan los cuatro elementos necesarios y suficientes para que se produzca: unos actores frente a un público en un espacio y durante un tiempo; elementos que serán en consecuencia los cuatro pilares de la teoría y del método analítico. Por su parte, la convención teatral «dobla» cada elemento representante (real) en «otro» representado (ficticio). Aunque resulte más difícil de apreciar, el público también se desdobla, lo mismo que el actor en personaje o el espacio y el tiempo reales en otros ficticios.

El modelo de comunicación que mejor da cuenta del teatro así concebido no es el presuntamente universal de tipo lineal («yo->tú» o «emisor $\longrightarrow$ receptor»), sino otro triangular, como cuando hablan dos interlocutores y una tercera persona asiste como observador; más aún, como cuando aquéllos hablan en realidad "para» ésta. Se trata de un modelo comunicativo definido por dos líneas perpendiculares: aquélla en la que interactúan los actores/personajes y aquella otra en que esa actuación se orienta a (es para) el público. Ni que decir tiene que esta segunda dirección es la genuinamente «teatral».

De acuerdo con los principios anteriores, importa entender el drama como el contenido, esto es, la cara representada o ficticia del teatro, pero condicionada, o mejor, configurada por el modo de representación; y definirlo en relación con las otras dos categorías que integran con él el «modelo dramatológico»: la fábula, en el sentido de los formalistas rusos, no de Aristóteles, o sea, la historia o el argumento, el mundo ficticio sin condicionamiento modal, considerado independientemente de su disposición representativa; y la escenificación o puesta en escena, que engloba el con-

${ }^{123}$ Cf. J.-L. GARCía BARRIENTOS, «"Modos” aristotélicos y dramaturgia contemporánea», en L. M. MonCADA (comp.), Versus Aristóteles: Ensayos sobre dramaturgia contemporánea, México, Anónimo Drama Ediciones, 2004, pp. 17-27 y 111; «Teatro y narratividad», Arbor, 699-700, 2004, pp. 509-524. 
junto de los elementos reales representantes. El drama es así la fábula escenificada, el argumento dispuesto para el teatro, la estructura que la puesta en escena imprime al universo ficticio que representa. Este modelo teórico, con la distinción entre los planos diegético (perteneciente a la fábula), escénico (a la escenificación) y dramático (a la relación o el encaje entre los dos anteriores) es la piedra angular de la teoría. Podemos decir ahora con mayor sencillez que dramatología y dramaturgia son, respectivamente, la teoría y la práctica del drama. Y que el drama así definido es una categoría común al texto y a la representación. Por tanto la teoría y el método de análisis (que lo son precisamente del «drama») deberían dar cuenta por igual del uno y de la otra.

Desde una concepción del teatro como espectáculo y del drama como teatro, propongo entender los textos como «documentos» de la efímera representación teatral; aunque siempre de carácter parcial, pues no hay manera de textualizar la entera experiencia intersubjetiva que es un espectáculo vivo, actuado, como el teatral. Entre los muchos y variados textos útiles para documentar el teatro, defino el texto dramático como la transcripción del drama contenido en un espectáculo teatral efectivo. Frente a este objeto puramente teórico, posterior a la representación y dependiente de ella, se impone definir el objeto real que leemos en forma de libro, que integra el correspondiente género literario y es por lo general anterior a las representaciones y en alguna medida independiente de ellas. Es lo que entiendo por obra dramática y defino como la codificación literaria (pero ni exhaustiva ni exclusiva) de un drama virtual o imaginado.

La autonomía literaria (relativa) así como sus característicos defectos y excesos de dramaticidad diferencian a la obra del texto. Éste depende, porque procede, de una puesta en escena particular y por eso puede transcribir todo y sólo lo que es rigurosamente dramático. La distancia entre obra y texto es la distancia entre literatura y espectáculo. Las ediciones que presentan entre corchetes partes de la obra que se suprimieron en la representación evidencian esa distancia: si omitimos lo que va entre corchetes, nos aproximamos al texto; si ignoramos los corchetes, a la obra. Se puede hacer una lectura teatral de la obra dramática, examinarla en cuanto obra de teatro. ¿Cómo? Leyendo en ella el texto dramático que contiene.

Pues bien, centrémonos ahora en este objeto que llamo «obra dramática» y que designa, en definitiva, los libros que efectivamente leemos, analizamos, comentamos o ponemos en escena. ¿Por qué digo que su autonomía literaria es relativa? Porque estoy, en contra de Veltruský ${ }^{124}$, de acuerdo con Ortega y Gasset en que «aun eso que, en verdad, tiene de literatura no puede contemplarse aislado de lo que la obra teatral tiene de espectácu-

\footnotetext{
${ }^{124}$ Op. cit.
} 
lo» ${ }^{125}$. Como justificación de esta tesis puede entenderse lo que sigue, donde trato de poner de manifiesto hasta qué punto el teatro determina los rasgos sustanciales de las obras dramáticas.

¿Qué sino la inmediatez del drama explica la estructura, peculiar, que es común al texto y a la obra dramática y consiste en la superposición de dos subtextos nítidamente diferenciados, el del diálogo y el de la acotación, y las características de cada uno? (No soy nada partidario, por cierto, del uso, por influjo innecesario del francés, de «didascalia» como sinónimo de acotación, término éste mucho más claro y preciso en español, sin el falso prestigio de lo raro.) En el diálogo, que es el componente estrictamente verbal del drama, dicho en la representación y transcrito (simplificado e incompleto) en el texto, la inmediatez modal se traduce en el dominio de lo que cabría llamar «estilo directo libre», sin régimen o mediación de ningún tipo, y en la plenitud funcional (y personal) del lenguaje; lo mismo que ocurre en la conversación «real», de la que es el trasunto literario más fiel. En la acotación, o sea la notación de los componentes extraverbales y paraverbales de la representación, efectiva o imaginada, de un drama, las consecuencias de la inmediatez representativa son mucho más sorprendentes e insólitas, rozando lo imposible. Pues la acotación es, en efecto, pura escritura «indecible», enunciación sin sujeto, lenguaje radicalmente impersonal y reducido a la función representativa, o sea, impermeable, entre otras, a la función poética. No se pueden escribir acotaciones en primera y segunda persona gramatical, ni tampoco en lenguaje literario, poético, figurado. Mejor dicho, sí se puede, pero no sirve de nada: es lo mismo que escribirlas en tercera persona y en lenguaje meramente funcional.

Común a la acotación y al diálogo es, pues, el carácter «objetivo» de la enunciación. Tiene razón Ubersfeld: «El primer rasgo distintivo de la escritura teatral es el no ser nunca subjetiva» ${ }^{126}$; pero la pierde al considerar al autor, traicionando ese «nunca», el «sujeto de la enunciación» de las acotaciones. Si la clave está, como ella misma dice, en la pregunta: ¿quién habla en el texto de teatro? ${ }^{127}$, la respuesta, por chocante que resulte, no puede ser más clara para mí: directamente cada personaje en el diálogo, y nadie — sí, nadie — en las acotaciones. Pues si realmente «hablara» el autor, como cree ella y quizás la mayoría, ¿por qué no puede nunca decir «yo»?

No sé si es preciso aclarar que esta configuración textual es privativa de la obra dramática, del todo distinta a la de la narración (y también a la del poema). Nada hay en ellos semejante a la acotación. Algo que podría parecerlo, la descripción, es siempre producto de una «voz», la del narra-

125 José ORTEGA y GASSET, Idea del teatro: Una abreviatura [1958], Madrid, Revista de Occidente, $1966^{2}$, p. 40.

${ }_{126}$ Anne Ubersfeld, Semiótica teatral [Lire le théâtre, 1977], trad. y adaptación de Francisco Torres Monreal, Madrid, Cátedra/Universidad de Murcia, 1989, p. 18.

127 Ibidem, p. 17. 
dor (o la del yo lírico); no escritura impersonal y muda, indecible, como es la auténtica acotación. Por su parte, el diálogo narrativo se diferencia radicalmente del dramático: frente a la inmediatez de éste, aquél está siempre «regido» por la voz del narrador. Y, todavía, además de las diferencias de diálogo y acotación por separado, es también exclusiva de la obra dramática la peculiar combinación de ambos, por ejemplo la impermeabilidad entre ellos, visible de forma práctica en la tipografía, que no se da en absoluto entre narración y diálogo en la novela (o en el poema).

Aunque cierre el apretado resumen anterior precisamente con los aspectos más estrictamente lingüísticos del teatro, no cabe duda de que éste rebasa como arte la creación verbal; lo que resulta tan evidente hoy como ya lo era en la Poética primigenia, no sólo porque dos de las seis «partes cualitativas» de la tragedia, la melopeya y el espectáculo, sean expresamente reconocidas como no verbales, sino también y sobre todo por la identificación fundamental de la poesía con la mimesis, que habría que traducir por «ficción», y la advertencia expresa de «que el poeta debe ser artífice de fábulas más que de versos, ya que es poeta por la imitación, e imita las acciones» ${ }^{128}$. Esta observación me permite concluir subrayando la apertura de la poética, no sólo a la retórica, en cuanto la literatura es una práctica verbal entre otras, sino también, en cuanto es una práctica artística entre otras, a la estética o, más precisamente, a las artes de la ficción. Son obvias, por ejemplo, las aportaciones de la narratología al estudio del relato fílmico.

El desbordamiento de la poética por esta otra orilla puede fertilizar el campo de unos «estudios culturales» más hondamente arraigados, más serios y disciplinares. Recuerdo haber especulado alguna vez acerca de sobre qué trataría, de haberla escrito Aristóteles en nuestros días, su Poética, si sobre lo que hoy llamamos literatura o más bien sobre cine ${ }^{129}$. Como si respondiera a esta cuestión, pero haciéndolo en realidad a la pregunta «-Y entre sus errores, si se quedara con uno solo...», responde George Steiner:

-No haber comprendido que la gran poética de la segunda mitad del siglo XX sería el cine. Y, asimismo, no haber medido la inmensidad del impacto de la web sobre todos los aspectos de la sensibilidad. En el futuro será necesaria otra poética distinta a la de Aristóteles. Estoy seguro [de] que llegará ${ }^{130}$.

Decididamente, prefiero al del nihilismo el error de la esperanza.

128 ARISTÓTELES, Poética, 1451b, ed. trilingüe por Valentín García Yebra, Madrid, Gredos, 1974, p. 160.

129 J.-L. GARCÍA BARRIENTOS, «Retórica del anacronismo en Las tres edades de Buster Keaton», en J. A. HERNÁNDEZ GUERRERO y otros (eds.), La recepción de los discursos: el oyente, el lector y el espectador, Cádiz, Servicio de Publicaciones de la Universidad / Ayuntamiento, 2003 (pp. 197-206), p. 197; ahora también en mi libro Teatro y ficción, cit. (pp. 211-222), p. 211.

${ }^{130}$ G. STEINER y François L'YvonNET, «George Steiner: «No hemos sabido dar a los jóvenes el error de la esperanza»» (Entrevista), El Cultural de El Mundo, 13-7-2006 (pp. 8-11), p. 11. 